\title{
Counter-narratives of achievement at South Africa's first apartheid-era black medical school, 1950s to the early 1990 s
}

\author{
Vanessa Noble*
}

\begin{abstract}
This article examines the construction and dissemination of two particular achievement narratives - one focused on high academic standards, the other on a Black Consciousness-inspired "Black pride" - that were produced by academic staff and students at the University of Natal's Medical School, South Africa's first apartheid-era black medical school in the highly racialised context of the 1950 s to early 1990 s. While quite different in terms of their producers and periods of origin, the article argues that both these narratives developed with a similar purpose: as counter-narratives, which intended to critique or challenge the pervasive and disparaging apartheid-era discourse that portrayed black South Africans as inferior. Indeed, both these narratives sought, in their own respective ways, to enable those producing them to reframe the dominant apartheid discourse, to offer alternatives, including more positive views about black South Africans, and to take an oppositional stance. Yet, while both developed as counter-narratives, they did so with different emphases and stances taken to challenge apartheid, highlighting the complexity of these narratives. In addition, this article examines how both these narratives could sometimes, in particular historical moments, overlap in time and even amalgamate, leading to the construction of hybridised narratives.
\end{abstract}

Keywords: Counter-narratives; medical education; University of Natal Medical School; apartheid; South African Students' Organisation (SASO); Black Consciousness.

\section{Opsomming}

In hierdie artikel word die konstruksie en verspreiding van twee besondere prestasienarratiewe bestudeer - een gerig op hoë akademiese standaarde, die ander op 'n Black Consciousness-geïnspireerde "Black pride" (Swart hoogmoed") - wat vervaardig is deur akademiesepersoneel en studente aan die Universiteit van Natal se Mediese Skool, Suid-Afrika se eerste swart mediese skool in die apartheids tydperk in die hoogs rassise konteks van die 1950s tot vroeë 1990s. Alhoewel dit heel anders is met betrekking tot hul produsente en oorsprongstydperke, voer hierdie artikel aan dat albei hierdie vertellings met 'n soortgelyke doel ontwikkel het: as teen verhale, wat

Vanessa Noble is a senior lecturer in the Historical Studies programme at the University of KwaZulu-Natal in South Africa. Her research focuses on the history of health and healing in southern Africa.

How to cite this article: V. Noble, "Counter-narratives of achievement at South Africa's first apartheid-era black medical school, 1950 s to the early $1990 \mathrm{~s}$ ", 
bedoel was om die deurdringende en neerhalende diskoers van die apartheid tydperk wat swart Suid-Afrikaners uitbeeld, te kritiseer of uit te daag as minderwaardig. Inderdaad, albei hierdie vertellings het op hulle eie maniere probeer om diegene wat hulle produseer in staat stel om die dominante apartheids diskoers te herformuleer, alternatiewe aan te bied, meer positiewe sienings oor swart Suid-Afrikaners te vorm en 'n opposise-standpunt in te neem. Alhoewel albei as teenverhale ontwikkel het, het hulle dit gedoen met verskillende beklemtonings en standpunte om apartheid uit te daag wat die kompleksiteit van hierdie vertellings beklemtoon. Daarbenewens word in hierdie artikel gekyk hoe albei hierdie vertellings, soms in die besonder historiese momente in tyd, kan oorvleuel en selfs kan saamsmelt, wat kan lei tot die konstruksie van hibridiese vertellings.

Sleutelwoorde: Teen narratiewe; mediese opleiding; Universiteit van Natal Mediese Skool; apartheid; South African Students' Organisation (SASO); Black Consciousness.

\section{Introduction}

Narratives are complex entities. They can be defined simply as stories or accounts of something that happened, such as an event or experience. They can, however, also be defined more complexly as mediated textual entities. In other words, entities created by people with particular interpretive viewpoints, in specific contexts, which shape their meanings. ${ }^{1}$ The second definition brings intentionality, and the contrived nature of narrative entities to the fore. This latter view of narratives, stimulated particularly by the thinking of literary and cultural studies scholars in the last few decades, has encouraged historians to ask new questions about their discipline's strongly held views about narrative objectivity and truth. ${ }^{2}$ Pushing beyond the chimerical truthfulness of historical narratives, scholars, influenced by this poststructuralist turn, have in recent years, analysed the constructed and contested nature of narratives, but also their power to effect and give meaning to people's lives. ${ }^{3}$

1. M. Hyvarinen, "Analysing Narratives and Story-Telling”, in P. Alasuutari, L. Bickman and J. Brannen (eds), The Sage Handbook of Social Research Methods (Sage, Thousand Oaks, 2008), p 448; and P.H. Abbott, The Cambridge Introduction to Narrative (Cambridge University Press, Cambridge, 2008), p 47.

2. See for example, P. Novick, That Noble Dream: The "Objectivity Question" and the American Historical Profession (Cambridge University Press, Cambridge and New York, 1988); L. Hunt (ed.), The New Cultural History (University of California Press, Berkeley, 1989); and I. Hofmeyr, "We Spend our Years as a Tale that is Told": Oral Historical Narrative in a South African Chiefdom (Heinemann, Portsmouth: NH, Wits University Press, Johannesburg and James Currey, London, 1993), p xi.

3. H. White, Tropics of Discourse: Essays in Cultural, Criticism (Johns Hopkins University Press, Baltimore, 1985), pp 81-100; A. Portelli, The Death of Luigi Trastulli and Other Stories: Form and Meaning in Oral History (State University of New York Press, New York, 1991); D.W. Cohen, The Combing of History (University of Chicago Press, Chicago and London, 1994); and M.R. Trouillot, Silencing the Past: Power and the Production of History (Beacon Press, Boston, 1995). 
This article focuses on two narratives that were prevalent during the latter half of the twentieth century in a particular South African medical educational context. My ideas for this article were solidified at an interdisciplinary workshop I attended towards the end of 2018, entitled "Narratives of Achievement in African and Afroeuropean Contexts". 4 It interrogated the "achievement principle"; particularly meritocratic achievement narratives, which focused on the importance of hard work (or effort) in accomplishing something, which has been used ubiquitously to explain or rationalise the success or progress of individuals or social groups. ${ }^{5}$

Particularly dominant within "Western" societies, this narrative also spread, through processes of European imperialism and other post-colonial interactions, to influence many societies around the world. ${ }^{6}$ While much scholarship has been published on the spread and impact, some studies critique this achievement narrative in Western societies, ${ }^{7}$ and the workshop sought to encourage its participants to help expand this historiography by analysing how notions of achievement were constructed and disseminated, but also negotiated and contested within different, historically specific African contexts.

4. This workshop took place between 30 October and 4 November 2018. It was hosted by the Stellenbosch Institute for Advanced Studies (STIAS) in collaboration with the Goethe University in Frankfurt, Germany in the framework of the Program Point Sud (funded by the German Research Foundation). Recently, a book was published with extended abstracts summarising papers presented by participants at this workshop. See E.U. Pirker, K. Hericks and M.M. Mbali (eds), Forward, Upward, Onward? Narratives of Achievement in African and Afroeuropean Contexts (HHU Books, Dusseldorf, 2020). I extend my thanks to the organisers and participants of this interdisciplinary workshop for giving me the opportunity to reflect, in new ways, on material collected for my $\mathrm{PhD}$ research.

5. E.U. Pirker, K. Hericks and M.M. Mbali, "Introduction", in Pirker, Hericks and Mbali (eds), Forward, Upward, Onward?, pp 1-2.

6. Although "Western" or "the West" has a long history dating back to Greco-Roman civilisation in Europe, its contemporary meaning includes the UK and Europe but also several countries such as those in North America, with large European ancestral populations. Today, these regions are regarded globally as wealthy, democratic and industrialised. For more on this, see "Reference Terms: Western World", at https://www.sciencedaily.com/terms/western_world.htm (accessed 15 September 2020).

7. See for example, D.C. McClelland, The Achieving Society (D. van Nostrand Company, New York, 1976); D.Y. Ford and J.J. Harris, "The American Achievement Ideology and Achievement Differentials among Preadolescent Gifted and Nongifted African American Males and Females", Journal of Negro Education, 61, 1, 1992, pp 45-64; G.H. Cuadraz, "Myths and the 'Politics of Exceptionality': Interpreting Chicana/o Narratives of Achievement", The Oral History Review, 33, 1, 2006, p 83; and J. Little, Against Meritocracy: Culture, Power and Myths of Mobility (Routledge, London and New York, 2018). 
This article seeks to add to this historiography by examining two achievement narratives produced by people who worked and studied at the University of Natal Medical School (UNMS, at the University of KwaZulu-Natal, as the university has been named since 2004), in South Africa's apartheid era. While the social and institutional history of this black ${ }^{8}$ medical school has been analysed in detail elsewhere, ${ }^{9}$ this earlier work did not focus specifically, as this article does, on this institution's history from the analytical lens of narrative constructions. Drawing primarily on a variety of sources from the 1950s to the early 1990s, it explores two specific achievement narratives that were envisioned and narrated by this institution's mainly white managers and teaching staff, but also its black students. ${ }^{10}$

The first part of this article examines an achievement narrative that stressed success through attainment of high academic standards. Constructed predominantly by university employees (its managers and teaching staff), but also many of its students, this narrative was influenced by and aligned with Western (particularly European) scientific models of medical excellence or standards of achievement. This narrative emerged strongly at the time of the opening of this medical school (early 1950s), and was commonly produced throughout the apartheid period.

The second part considers an alternative narrative that emerged from the late 1960s amongst a particular group of black student activists at this school, who were frustrated by Western-inspired ideologies and racialised structural inequalities. Stirred by defiant anti-apartheid Black Consciousness philosophies, their narratives, which ran parallel for a time to those producing a high standards-focused narrative, interrogated and reimagined achievement. These student activists' narratives did not focus on the attainment of high academic standards to undercut their apartheid detractors, but offered up their own scripts of success for black students, which focused on celebrating black historical and cultural feats and the struggle to achieve political freedom in apartheid South Africa.

This article argues that although those promoting these narratives had different understandings of achievement, both sets of narratives developed with a similar purpose. Analysed historically, these narratives developed as positive counter- (or oppositional) narratives in a repressive context that sought to critique or challenge, in

8. Since this article focuses primarily on the apartheid era, the use of racial labels to refer to people is unavoidable for explanatory clarity. Although recognising such terms as socially constructed and highly contentious, this article uses the terms 'African', 'Indian', 'coloured' and 'white', as well as 'black' (to refer jointly to 'Africans', 'Indians' and 'coloureds') as they are widely used in South Africa today.

9. V. Noble, A School of Struggle: Durban's Medical School and the Education of Black Doctors in South Africa (University of KwaZulu-Natal Press, Pietermaritzburg, 2013).

10. This article drew on various sources from the apartheid period, such as institutional records, staff and student publications and newspaper articles. Additionally, it drew on interviews with those who studied and/or worked at the UNMS during apartheid. All interviews used in this article, unless otherwise indicated, were conducted by the author between 1999 and 2004. 
their own respective ways, the pervasive and deleterious apartheid-era discourses that branded black South Africans as subordinate or inferior. In addition, this article considers the complexity of such narratives, which could sometimes overlap, not only in time, but also in content, leading to the production of hybrid achievement counternarratives, when elements of both narratives were amalgamated by producers at particular historical moments.

\section{Narrative 1: Success through attainment of high academic standards}

A careful reading of various sources from the apartheid period highlights a common narrative, constructed by various UNMS managers and staff, as well as students, that focused on success through the attainment of high academic standards. In September 1951, the University of Natal's vice chancellor, E.G. Malherbe, captured this perspective in a speech delivered at the opening of the medical school:

In case there should be any doubt as to the kind of medical education that will be provided in this school, let me remind you that, in addition to the high standards, which in any case the University of Natal will itself insist upon, there is also the guarantee provided by external authority - that of the South African Medical and Dental Council, which must approve of the degree to be given before those who hold it can be placed upon the medical register of the Union. A high standard of qualification is thus assured. ... Let the world take note of what is being done here today. We are opening a College, which is to provide, for non-Europeans, a training in medicine no whit inferior to that provided for Europeans. ${ }^{11}$

George W. Gale, the dean at the UNMS between 1952 and 1955, produced a similar narrative in a memorandum requesting additional funds to complete the building of this medical school:

It [is] ... essential to ensure that the standards of this School are at least equal to those of other medical schools in the Union, in order to secure recognition of its degrees by the South African Medical and Dental Council for the purposes of medical registration of those who hold them. But it is also very necessary to show - to a still sceptical public ... that a separate school for non-Europeans does not imply an inferior school. ${ }^{12}$

This standards-focused achievement narrative was constructed and disseminated by the school's managers and staff repeatedly during the 1950s, the first decade of the

11. National Archives, Pretoria (hereafter NAR), GES 1831 68/30 Medical and Dental Training for Natives, "Opening of the Wentworth College, University of Natal", 11 September 1951, pp 4-5.

12. Campbell Collections, Durban (hereafter CC), Gordon Papers (hereafter GP), File 13 KCM 25748, G.W. Gale, "University of Natal Memorandum on the Financial Needs of the Medical School”, 15 April 1952 (submitted to the University Development Foundation), $\mathrm{p} 1$. 
founding of the UNMS, but was ubiquitous throughout the apartheid period. ${ }^{13}$ For example, in the late 1960s, Isidor Gordon, a professor of Pathology and Forensic Medicine, who was also the dean at the time, made the following statement, on behalf of the UNMS, at a Committee of Investigation of Medical Education:

... the positive achievements of the medical school ... [t]he success achieved in the medical education of non-whites is in no small measure due to the Faculty of Medicine being a Faculty of the University of Natal and as such, standards, reputation and discipline have been accepted as conforming to that of a University of proven standing. ${ }^{14}$

Other members of the teaching staff, produced a comparable focus in their writings during the 1970s through to the early 1990s. As John V.O. Reid, professor of Physiology, highlighted in a University of Natal publication in the late 1970s:

[T] heir medical training was modelled closely on that of existing 'white' schools in the country if only because a departure from that would have carried too strong a connotation of something different, something inferior. It was a simple case of trying to put out doctors comparable to those produced from the other schools of the country, who are of high quality. ${ }^{15}$

13. For similar narratives, see NAR GES 2957 PN5, G.W. Gale, "The Durban Medical School (Faculty of Medicine - University of Natal)”, 15 May 1952; Nelson R. Mandela School of Medicine Archive (hereafter NRMSMA), "The Medical Course at the University of Natal for the Degree of M.B., Ch.B.", 15 October 1954; University of KwaZulu-Natal Archive (hereafter UKZNA), The University of Natal Durban Medical School: A Response to the Challenge of Africa (Hayne \& Gibson, Durban, 1954), p 28; "The Durban Medical School: A Progress Report", South African Medical Journal (hereafter SAMJ), 7 May 1955, p 439; UKZNA, I. Gordon, "Medicine as a Career for Non-Europeans", University of Natal Gazette, June 1956, p 21; G.W. Gale, "Medical Schools in Africa: A Short and Contemporary Survey", Journal of Medical Education, 34, 8, August 1959, pp 716-717.

14. NAR K296 E5/49, Medical Training Komitee van Ondersoek oor Mediese Opleiding (KOMO), 1968-1969, "Memorandum prepared by the University of Natal for Submission to KOMO", pp 8, 12. For similar narratives produced in the 1960s, see V.K.G. Pillay, "Some Thoughts on Intern Training", SAMJ, 2 December 1961, p 1026 and CC, Mouldy Box, Tied together 2 - File Dr Taylor 1962, Letter from Dr A.B. Taylor to "friends", 4 November 1962, p 4.

15. UKZNA, J.V.O. Reid, "The Concept of the Medical School”, Concept: Convocation of the University of Natal, 7, 1976, pp 3-4. For similar narratives produced in the 1970s, see UKZNA, "Silver Jubilee", Natal University News, 20, 1976, p 8; NRMSMA, "University Fights for its Blacks", Natal Mercury, 24 February 1976; UKZNA C205/1/1-3, "A Reprieve for Black Medical Course", Natal Mercury, 7 August 1976; "To the Editor: Signed by 17 Professors of the Faculty of Medicine, UN, Durban, re Phasing out of Admissions of Non-White Students to University of Natal Medical School", SAMJ, 21 February 1976, p 235; and Sefako Makgatho Health Sciences University Archive (hereafter SMHSUA) MEDUNSA Press Cuttings 1977-82, "Varsity to Tackle Koornhof on Black Students", Pretoria News, 17 October 1977. 
In addition, Professor P. de V. Booysen, the vice-chancellor and principal of this same institution, conveyed a similar sentiment in his statement in the mid-1980s, in a special issue focused on this university's 75th anniversary in the South African Medical Journal:

[Our] medical school [is] unique ... in its history, its contributions to many branches of medical science and, most significantly, its commitment to the teaching of black medical students. ... The continuing success of the University of Natal Medical School has largely been due to the dedication of its staff, many of whom have been and are ex-students. The school's achievements, which are legend, are manifested in the internationally accorded recognition of its contribution to the medical profession. ${ }^{16}$

UNMS students produced high standards-focused narratives too. This is evident, for example, in a 1958 student publication. Celebrating the school's first cohort of graduates, an unnamed student wrote:

We congratulate these people on their splendid performance, and we commend them for their courage in coming ... to a segregated school. To start with, there were murmurs of disapproval from many angles. But it was not long before a determined staff convinced the world that the doctor[s] produced here would be inferior to none.... [T] he first 12 doctors were produced at the end of last year, and the standards acquired compare with those of any doctor in the country...17

In the 1970s, B.T. Naidoo, a graduate of this medical school and a part-time lecturer by the time of the production of this Natal University News publication, also constructed a comparable achievement narrative:

Statistically, one must place the Natal Medical School's greatest achievement over the past 25 years as the provision of 612 much-needed black doctors for South Africa. Behind this bald figure, however, lies not only the foundation of a black medical profession of the highest standard, but also the gradual evolution of a medical faculty, which attracts international recognition for its excellence. ${ }^{18}$

16. P. de. V. Booysen, "Message from the Vice-Chancellor and Principal of the University of Natal", SAMJ, 23 November 1985, p 776. For similar narratives in the 1980s and early 1990s, see UKZNA BIO-S 475/1/1, Adams, E.B., "Graduation Address: Professor E.B. Adams", Embargo, 14 April 1984, pp 1-2; UKZNA, "40 Years of Excellence", NU Focus, 2, 2, Autumn 1991, p 18; and "Medical School: 40 Years On: Messages of Goodwill: From Professor Derek Arbuckle, Dean of the Faculty of Medicine", NU Focus, 2, 3, Winter 1991, p 43.

17. UKZNA MQ 1/1/1-5, "Editorial”, The Amoeba, 1, 4, April 1958, p 6. Also see "A Student's View on the Stand of our Staff as Regards the Separate University's Bill" in the same edition, p 21; and UKZNA MQ 1/1/1-5, Comment by Student, The Amoeba, 2, 6, 1 September 1954, p 1.

18. UKZNA, B.T. Naidoo, "The First Twenty-Five Years", Natal University News, 20, 1976, p 9. For similar focused narratives, also see H.N. Desai, "To the Editor re Twenty-Fifth Anniversary Tragedy", SAMJ, 13 March 1976, p 423; and NRMSMA, Medical Students Representative Council Minutes, "A Brief History of the Faculty of Medicine, University of Natal", 1978. 
Similar high standards-focused narratives were also fashioned by students in the 1980s and early 1990s. ${ }^{19}$

This set of narratives can be examined using different analytical lenses. One useful approach is to consider the influence of people's individual psychologies. It is conceivable that some staff and students arrived at the UNMS with an achievementoriented mind-set, already deeply ingrained from their prior experiences, which influenced the focus of their narratives. Certainly, many of its teaching staff had succeeded in attaining degrees, some from prestigious overseas universities, such Edinburgh and Oxford, and would not have taken up positions in Durban unless they were convinced of the standards of this medical school to build successful careers. ${ }^{20}$ Its development by and within an established university, and its recognition by the country's regulatory body, the South African Medical and Dental Council (SAMDC), was accepted as proof of this. Furthermore, many of the students had excelled in their studies to gain admission to the medical school, having been "the highest achievers" in their high schools, if not the best in their entire school districts. ${ }^{21}$ As was the case at other medical schools, admissions were highly competitive with limited spaces available for applicants each year. ${ }^{22}$

It is plausible too that the University of Natal's organisational framework influenced the narrative constructions of some staff and students. As several scholars demonstrated, organisational or institutional narratives influenced individuals who, consciously or unconsciously, restructured their narratives to align them with something bigger, an overarching or collective organisational story or narrative, to provide them with a sense of belonging or to give a sense of meaning to their experiences. ${ }^{23}$ This is evident in the fact that several of the quotations cited above

19. NRMSMA, "Phasing-Out”, MSRC Bulletin, Special Edition, May 1982; UKZNA, "Messages: Dr U.G. Lalloo, President, MGA" in P. Duminy and A. Mason, The University of Natal Medical School, 1951-1991: Meeting the Challenge of Change (brochure produced to mark the 40th anniversary of the Faculty of Medicine, 1991), pp 5-6 and UKZNA, University of Natal Medical School Reconciliation Graduation Booklet (Indicator Press, Durban, 1995), pp 7, 11-17.

20. NAR, K296 E5/49 "University of Natal: Memorandum prepared by the University of Natal for Submission to the Committee of Enquiry into Medical Education", p 12. See also CC, GP File 22 KCM 25885, "University of Natal Faculty of Medicine Durban: General Information for Undergraduate Studies Academic Year 1956", pp 1-3 for more on the teaching staff's academic degrees.

21. Interviews with M.J. Matjila, Durban, 11 July 2003; H.J. Coovadia, Durban, 24 June 2003; and M.B. Kistnasamy, Durban, 26 August 2003. See also M.W. Makgoba, Mokoko: The Makgoba Affair: A Reflection on Transformation (Vivlia Publishers, Florida Hills), pp 31, 47.

22. The UNMS admitted an estimated 35 to 40 new students per annum in the 1950 s. This number increased to about 80 by the mid-1970s, and roughly 120 by the early 1990s, though many more students applied each year than were spaces available. See Noble, A School of Struggle, pp 3, 71.

23. For more on this, see Y. Gabriel, "Narratives and Stories in Organisational Life", in A. de Fina and A. Georgakopoulou (eds), The Handbook of Narrative Analysis. (Wiley, 
appeared in University of Natal publications, such as official marketing brochures, staff or student newsletters, periodicals, or anniversary publications. ${ }^{24}$ Geared towards bolstering the public perception of this university, or celebrating its success stories, their submissions would have been tailored to fit within the institution's larger, celebratory achievement-oriented memory making agenda. We can assume that the editors of these publications would not have published their narratives had they not constructed them to fit collective ones.

Although individual and organisational memory-making influences should be regarded as key factors affecting the production, meanings and purposes of staff and students' high standards-focused achievement narratives, to better understand them, these narratives must also be situated within their broader historical context.

When viewed in historical perspective, one can see how European standards were pivotal in moulding the development of South Africa's medical profession. This stemmed from a long history of colonial contacts and comparisons with the United Kingdom (UK) and Europe, where European medical education and practice models came to be viewed as being of a "high standard" compared to those in the colonial peripheries. $^{25}$ Certainly, until 1918, just eight years after South Africa had become a self-governing dominion of the British Empire, South Africans could still not train as doctors in their own country because the medical authorities, made up mostly of UKtrained doctors at the time, did not regard South African universities as good enough to provide a comparable standard of training. ${ }^{26}$ Instead, they had to travel overseas, to places such as London, Edinburgh, Dublin, Paris and Leiden to receive their training, a costly affair, which meant completing a rigorous five or six year biomedical training, where students were expected to advance each year, by successfully completing and passing examinations in various preclinical and later clinical science-based subjects. ${ }^{27}$

Chichester, 2015), pp 275-292; and C. Linde, "Narrative in Institutions", in D. Shiffrin, D. Tannen and H. Hamilton (eds), The Handbook of Discourse Analysis (Wiley-Blackwell, Oxford, 2003), pp 518-536.

24. Even marketing brochures published after 1994 highlight a celebratory, high standards-focused achievement narrative. See for example, UKZNA, J. Moodley and S. Maharaj (eds), University of Natal Nelson R. Mandela School of Medicine: 50 Years of Achievement in Teaching, Service and Research (Communications Office, University of Natal Nelson R. Mandela School of Medicine, 2001).

25. J.H. Louw, In the Shadow of Table Mountain: A History of the University of Cape Town Medical School and its Associated Teaching Hospitals up to 1950, with Glimpses into the Future (Struik, Cape Town, 1969), pp 137-143; and A. Digby, "Introduction", in A. Digby and H. Phillips with H. Deacon and K. Thomson, At the Heart of Healing: Groote Schuur Hospital, 1938-2008 (Jacana, Auckland Park, 2008), p xxiii.

26. Louw, In the Shadow of Table Mountain, pp 1-77.

27. By biomedical, I mean a training that entailed a professionally-organised and staterecognised (i.e. one which required university training and state licensing) scientific healing ethos. In the early twentieth century, South Africa's biomedical curriculum, in line with European models, included the teaching of preclinical science subjects, such as physics, chemistry, botany, zoology, anatomy and physiology, pathology, bacteriology, and pharmacology. Students then went on to do their clinical training in 
Moreover, when the University of Cape Town (UCT) was eventually allowed to offer a full biomedical qualification from 1918, followed a few years later by the University of the Witwatersrand (Wits), the shadow of European medical standards continued to loom large. ${ }^{28}$ Unquestionably, as pioneers of these new institutions, UCT and Wits managers and staff, themselves graduates of overseas universities and under enormous pressure from opponents of this local training, sought to emulate as closely as possible what they regarded as the "best" European academic standards at their schools. ${ }^{29}$ To ensure their standards, their activities were also monitored closely by the country's medical regulatory body, the SAMDC. ${ }^{30}$ Known as the Colonial Medical Council in the nineteenth and early twentieth centuries, the renamed SAMDC (in 1928), which was made up for decades by overseas-trained doctors, sought to ensure that South Africa's medical education and practice standards were on par with international standards.

Thus, decades before the UNMS even opened its doors, a European, particularly British-influenced, standards-focused achievement narrative was already wellentrenched in South Africa's medical educational environment. Considered from this viewpoint, it is not a leap to see how this narrative would have influenced those at the UNMS. Although this medical school introduced two add-ons to their curriculum in the 1950s; a preliminary year and the requirement that students complete an extra clinical major in the subject of Social, Preventive and Family Medicine, it was careful to emphasise these aspects as "additions" to the country's approved medical curriculum, ${ }^{31}$ seeking to align its curriculum as closely as possible with scientific preclinical and clinical content and assessment models produced by South Africa's leading medical schools, and as laid out by the SAMDC. ${ }^{22}$ Undeniably, examining this

medicine, surgery, and obstetrics and gynaecology, as well as other ancillary subjects, and also received practical training in a teaching hospital/s. See Louw, In the Shadow of Table Mountain, pp 92-118.

28. Louw, In the Shadow of Table Mountain, pp 109, 139-140. For more on the establishment of Wits's medical school, see B.K. Murray, Wits the Early Years: A History of the University of the Witwatersrand Johannesburg and its Precursors 1896-1939 (Wits University Press, Johannesburg, 1982), pp 3, 15-16, 74, 93, 177 and 184.

29. Louw, In the Shadow of Table Mountain, pp 72-73, 94, 139-140; Murray, Wits the Early Years, pp 93-94, 151-153, 156, 177, 244-247.

30. I. Gordon, "Medical Education in the Republic of South Africa", Journal of Medical Education, 37, September 1962, pp 920-923.

31. The "preliminary" (year 0) sought to give students with lower passes in maths, science and English, an additional year to complete the foundation level premedical subjects. The extra major sought to provide students with a training in preventive and community-oriented aspects of medicine. These additions extended the degree from six to seven years. For more on this, see V. Noble, "A Medical Education with a Difference: A History of the Training of Black Student Doctors in Social, Preventive and Community-oriented Primary Health Care at the University of Natal Medical School, 1940s-1960", South African Historical Journal, 61, 3, 2009, pp 550-574.

32. UKZNA, "Faculty of Medicine: Information for Students", University of Natal Calendar, 1954, pp 363-364; and CC, GP File 22 KCM 25885, "University of Natal Faculty of Medicine Durban: General Information for Undergraduate Studies Academic Year 
earlier medical education history helps us to realise that UNMS staff and students' narratives quoted earlier were not unique but were instead embedded within a longer history of concern with achieving high scientific academic medical standards.

Furthermore, to better understand these narratives, we need to situate them within the circumstances of racial segregation in the twentieth century. The UNMS was developed in a specific context where various successive governments used 'race' (i.e. a person's skin colour) to rank and separate the country's population, and promulgated numerous laws that created advantages for white South Africans and disadvantages, and thus inequalities, for black South Africans. ${ }^{33}$ This influenced the realm of medical education too, which saw a long history of exclusion of black South Africans from its early medical schools on the basis of a pervasive, racist set of views created by prejudiced government officials, a variety of scholars, including many scientists, anthropologists and educationalists and by countless white citizens who supported a segregationist policy agenda. This hegemonic discourse constructed black South Africans as inferior to whites. ${ }^{34}$

This discourse permeated the medical profession too. In the early twentieth century it remained divided between those who supported a full biomedical training for black South Africans, and those (the majority) who believed that black students were not in possession of the required intellectual acumen to complete a medical degree and should thus be offered an inferior training. ${ }^{35}$ In the early 1930s, the viewpoint expressed by the Thornton Commission, appointed by the government to investigate the issue of black medical education, asserted that black students should not be trained at white institutions, while the expense of creating a black medical school of the same standard as those at UCT and Wits was not "practical". ${ }^{36}$ Consequently, black South Africans, interested in training as doctors, were either required to go overseas for their training, ${ }^{37}$ or to complete shorter "assistant" or "aid"

1956", pp 4-5. All medical schools in South Africa had a representative on the SAMDC to ensure adherence to minimum standards as set by this council. See Gordon, "Medical Education in the Republic of South Africa", p 920.

33. For more on the development of South Africa's racialised past, see W. Beinart and S. Dubow (eds), Segregation and Apartheid in Twentieth Century South Africa (Routledge, London and New York, 1995); and D. Posel, The Making of Apartheid 1948-61: Conflict and Compromise (Clarendon Press, Oxford, 1991).

34. See S. Dubow, Scientific Racism in Modern South Africa (Cambridge University Press, Cambridge, 1995); and P. Christie and C. Collins, "Bantu Education: Apartheid Ideology and Labour Reproduction", in P. Kallaway (ed.), Apartheid and Education (Ravan Press, Johannesburg, 1984), pp 170-183.

35. K.A. Shapiro, "Doctors or Medical Aids: The Debate over the Training of Black Medical Personnel for the Rural Black Population in South Africa in the 1920s and 1930s", Journal of Southern African Studies (hereafter JSAS) 13, 2, 1987, pp 234-255.

36. Shapiro, "Doctors or Medical Aids", p 251.

37. See for example, K. Goonam, Coolie Doctor: An Autobiography (Madiba Publications, Durban, 1991); and S. Gish, Alfred B. Xuma: African, American, South African (Macmillan Press, London, 2000). Overseas-trained black doctors, such as A.B. Xuma, made a strong 
training courses which provided lower level qualifications and limited work opportunities under the supervision of white doctors. ${ }^{38}$ This remained the situation until the early 1940s, when a small number of black South Africans gained admission to UCT and Wits medical schools for the first time, in the more reformist context of World War Two. ${ }^{39}$

Therefore, when the UNMS opened in the city of Durban in 1951, it was an important accomplishment in itself, an institution hard fought for over decades by many who sought to promote a full biomedical training for black South Africans. ${ }^{40}$ However, it operated right through to 1994 as a compromised solution in a racial segregation context. Opened just two and a half years after the Afrikaner Nationalistled government came to power in South Africa on a platform of further entrenchment of apartheid policies, this government helped to subsidise the medical school but made it a condition that the UNMS could only accept black students. ${ }^{41}$ Undoubtedly, the government's eventual decision to place the institution under the aegis of the University of Natal, a historically white university in terms of its staff and students, was influenced by the development of a "Non-European Section" from 1936, which offered parallel but racially separate classes (usually at nights or on weekends) for black students for certain courses. ${ }^{42}$ This paved the way for the creation of a geographically separate medical campus, whose administrative and teaching staff were primarily white, ${ }^{43}$ while the student body was exclusively black. ${ }^{44}$

case for South African medical schools to provide a full medical qualification for black students to maintain the profession's high standards.

38. For more on two efforts to provide shortened medical training schemes for black South Africans, see Shapiro, "Doctors or Medical Aids", pp 234-255; and J. Parle and V. Noble, The People's Hospital: A History of McCords, Durban, 1890-1970s (Natal Society Foundation, Pietermaritzburg, 2017), pp 47-55, 59-60.

39. For more on the reasons for this, see B.K. Murray, "Wits as an 'Open' University 19391959: Black Admissions to the University of the Witwatersrand", JSAS, 16, 4, 1990, pp 652-676; and H. Phillips, The University of Cape Town, 1918-48: The Formative Years (UCT Press, Cape Town, 1993), pp 192-193. Their numbers were rarely more than $5 \%$ or $6 \%$ of these universities' total medical student populations.

40. For more on the complex factors that eventually led to the opening of South Africa's fourth medical school in the province of Natal, see Noble, A School of Struggle, chapters 1 and 2.

41. Gordon, "Medical Education in the Republic of South Africa", pp 924-925.

42. By 1948, there were 327 black students enrolled at the University of Natal. See UKZNA, Help your People: The Natal University Non-European Section: Appeal for Funds (Hayne \& Gibson, Durban, 1953), pp 6-7. For more on this university's "Non-European Section", see S. Vietzen, "Mabel Palmer and Black Higher Education in Natal, 19361942", Journal of Natal and Zulu History, 6, 1, 1983, pp 98-114.

43. During the apartheid years, the UNMS gradually appointed more black South Africans to the teaching staff as they graduated from the institution. See Noble, A School of Struggle, p 158.

44. Between 1957 and 1994, the UNMS produced 2413 black medical doctors, the largest number trained in South Africa. See Noble, A School of Struggle, $\mathrm{p} 3$. 
Created as the fourth medical school, the UNMS was the first to provide a full, albeit segregated, biomedical training for black South Africans in apartheid South Africa. ${ }^{45}$ Therefore, it experienced similar pressures to meet standards as pioneers, as had been the case at UCT and Wits decades earlier. Similar to their earlier established counterparts, the UNMS also encountered much scepticism and criticism by people who questioned the school's quality of medical education. What was different, however, was that notions of superiority and inferiority were reframed from earlier metropole-colony based standards and comparisons to white-black (i.e. racialised) ones. Certainly, as we saw from the earlier quotations, the pervasive view that equated "non-Europeans" with inferiority in South Africa was never far from the minds of UNMS staff and students, who felt the need to defend or promote themselves, their school and their qualifications from being seen as of "lower standard" or "second grade". ${ }^{46}$ As Professor Reid captured it: "[W]e always had this feeling ... the whole place had this thing around its neck, 'You are for blacks only"', and thus "not up to standard". ${ }^{47}$

Although some staff and students kept their heads down and quietly went about their business, continuing with their jobs or studies, not everyone accepted this disparaging discourse as fait accompli. Indeed, looking at these standards-focused achievement narratives again, one can argue that they operated as "counternarratives". Examined in a wide range of academic fields, scholars have argued that counter-narratives are designed to oppose or challenge negative or "deficit discourses" of the established order.48 As Lundholt, Maagaard and Piekut assert, counternarratives are the stories people tell which:

45. Following UCT and Wits, a third white medical school was established at the University of Pretoria in 1943. See Gordon, "Medical Education in the Republic of South Africa", p 920.

46. Interview with F.G.H. Mayet, Durban, 4 June 1999. Also see UKZNA MQ 1/1/1-5, "Editorial", The Amoeba, 1, 2, 12 October 1953, p 1; and "A Student's View on the Stand of our Staff as Regards the Separate University's Bill”, The Amoeba, 4, April 1958, p 21. See also Interview with Y.K. Seedat, Durban, 7 July 2003.

47. Interview with J.V.O. Reid, Plettenberg Bay, 16 June 2002.

48. This concept has been analysed in the fields of education, language and communication, sociology, psychology and critical race theory. See for example, S.R. Harper, "Niggers No More: A Critical Race Counternarrative on Black Male Student Achievement at Predominantly White Colleges and Universities, International Journal of Qualitative Studies in Education, 22, 6, 2009, pp 697-712; M. Bamberg and M. Andrews (eds), Considering Counter-Narratives: Narrating, Resisting, Making Sense (John Benjamins, Amsterdam, 2004), p 4. See also D.G. Solórzano and T.J. Yosso, "Critical Race Methodology: Counter-Storytelling as an Analytical Framework for Educational Research", Qualitative Inquiry, 8, 1, 2002, pp 23-44. 
... oppos[e] or resist... socially and culturally informed master narratives ... which are often normative or oppressive, or exclude perspectives or experiences that diverge from those conveyed through master narratives. In this sense, counter narratives play a role in storytellers positioning themselves against, or critiquing [either implicitly or explicitly], the themes and ideologies of master narratives. ${ }^{49}$

Reading earlier quotations in the light of the counter-narrative concept, one can see that they too reflect a desire to counter an apartheid discourse that branded black medical education in South Africa as inferior. Besides enabling people to voice alternative or oppositional views, one can argue that these standards-focused achievement narratives also sought to detract from or subvert negative images. In a context where the state sought to undermine the feats of black South Africans relentlessly in all areas of life, this narrative was designed to motivate people and to reframe the discourse positively in a way designed to prove the naysayers wrong by focusing on high-standards, lofty pursuits and commendable "achievements" of those working and studying at the UNMS.

Furthermore, beyond producing oppositional views, this standards-focused achievement narrative was also, on occasion, used to rally support against unpopular government directives, which sometimes worked to disrupt these directives. A good example are the protests that took place against the state's plan, communicated to the University of Natal in 1957, to transfer the medical school from its control, and to place it under the administrative control of the Department of Bantu Education. ${ }^{50}$ This plan formed part of the state's wider strategy to implement more rigorous segregation at the higher education level by creating several black university colleges to accommodate black students. Mobilised primarily by the school's academic staff, this narrative was constructed to oppose vehemently what they regarded as "the depreciation of standards" should this transfer occur. ${ }^{51}$ Their protest, which culminated in a threat to resign en masse if the government proceeded with its plan, generated so much backlash in the public domain that it forced the state to back down on its plan. ${ }^{52}$ Instead, when the Extension of University Education Act, ratifying fuller

49. M.W. Lundholt, C.A. Maagaard and A. Piekut, "Counter-Narratives”, Wiley Online Library, https://onlinelibrary.wiley.com/doi/full/10.1002/9781119010722.iesc0201 (accessed on 20 September 2020).

50. See Murray, Wits the 'Open' Years, particularly chapters 9 and 10; and Noble, A School of Struggle, pp 83-87.

51. UKZNA MQ 1/1/1-5, "Editorial", The Amoeba, 1, 4, April 1958, p 6. Also see "Medical School Move: Fears of Fall in Standards", Cape Argus, 11 March 1957.

52. CC KCM 57009 (12) E.G. Malherbe File 463/7/2, "Unanimous Resolution passed at a Meeting of Medical School Staff (Numbering over 100) on 5 March 1958". For more on this, see the many newspaper and other sources collated into three reports by I. Gordon, Report on the Government's Intended Action to Remove the Faculty of Medicine from the University of Natal (Hayne \& Gibson, Durban, 4 March 1957); Further Report on the Government's Intention to Remove the Faculty of Medicine from the University of Natal (Hayne \& Gibson, Durban, 4 May 1957); and Third Report on the Government's Intention to Remove the Faculty of Medicine from the University of Natal (Process Printers, Durban, 25 February 1958). 
segregation at the tertiary level was eventually passed in 1959, a clause in this Act exempted the UNMS, while other university institutions, including UCT, Wits and the University of Natal's "Non-European Section", were forced to close their doors to black students unless prior ministerial approval was obtained.

Relatively few black medical students involved themselves - publicly anyway in anti-apartheid activities in the 1950s and early 1960s. This was probably a consequence of many factors, including a gruelling work schedule, the pressure placed on early generations to succeed academically, and an unpropitious political climate that saw the promulgation of new apartheid laws and mass arrests, detentions and imprisonment of a whole generation of political activists. ${ }^{53}$ However, as we shall see in the next section, a stronger anti-apartheid oppositional student movement emerged from the late 1960s. It also developed a robust achievement-focused counter-narrative, one with a markedly different interpretation of achievement.

\section{Narrative 2: A Black Consciousness-inspired counter-narrative of achievement}

In the late 1960s, an alternative counter-narrative emerged, constructed primarily by black students. Produced by Black Consciousness-inspired student activists who belonged to the South African Students' Organisation (SASO), this narrative also sought to critique and challenge the master discourse that branded black South Africans as inferior. ${ }^{54}$ However, unlike those who focused on achieving the highest Western scientific medical standards to challenge their naysayers, students who shaped this narrative questioned Western ideologies and reconceptualised achievement, seeking to inspire students to challenge their apartheid oppressors in a more strident manner.

During the late 1960s and through the 1970s, SASO student activists captured their defiant anti-apartheid sentiments in their speeches and written documents. An early leader of this organisation, Steve Biko wrote the following about white South

53. For more on this see UKZNA MQ 1/1/1-5, A.B.T. Mohlomi, "A Review of Student Organisation", The Amoeba 1, 2, 16 September 1952; V.R. Makgalomele, "Editorial: Wentworth Aspect", The Amoeba 1, 3, 14 October 1952. See also L. Kuper, An African Bourgeoisie: Race, Class, and Politics in South Africa (Yale University Press, New Haven: CT and London, 1965), p 154; E.H. Brookes, A History of the University of Natal (University of Natal Press, Pietermaritzburg, 1966), pp 165-166; and Interview with B.T. Naidoo, Durban, 10 November 2003.

54. There is much written on the Black Consciousness Movement (BCM) in South Africa. See for example, G.M. Gerhart, Black Power in South Africa: The Evolution of an Ideology (University of California Press, Los Angeles, 1978); B. Pityana, M. Ramphele, M. Mpumlwana and L. Wilson (eds), Bounds of Possibility: The Legacy of Steve Biko and Black Consciousness (David Philip and Zed Books, Cape Town and London, 1991); S. Badat, Black Student Politics: Higher Education and Apartheid, from SASO to SANSCO, 1968-1990 (Routledge, New York and London, 1999); D.R. Magaziner, The Law and the Prophets: Black Consciousness in South Africa, 1968-77 (Jacana, Johannesburg, 2010); and I.M. McQueen, Black Consciousness and Progressive Movements under Apartheid (University of KwaZulu-Natal Press, Pietermaritzburg, 2018). 
Africans and their racially divisive policies, in a paper delivered at an Inter-Racial Studies conference that took place in Cape Town in January 1971:

So blatantly exploitative in terms of the mind and body is the practice of white racism ... The white man's quest for power has led him to destroy with utter ruthlessness whatever has stood in his way. In an effort to divide the black world in terms of aspirations, the powers that be have evolved a philosophy that stratifies the black world and gives preferential treatment to certain groups. .55

These activists' writings also took aim at leftist-leaning "white liberals", or what Biko called "non-conformist ... do-gooders", who sought to "help" black South Africans in their struggle against apartheid.56 In his article, "White Racism and Black Consciousness", he criticised such individuals for not going far enough to champion the rights of black South Africans and for speaking on their behalf, thus undermining their agency. For Biko, the calls for gradual reform of the apartheid system and slow-moving racial integration "was impossible to achieve in South Africa" because it was "foisted on two parties whose entire upbringing had been to support the lie that one race was superior and the others inferior". For this activist, one needed to "overhaul the whole system in South Africa before hoping to get black and white walking hand in hand to oppose a common enemy". ${ }^{5}$

In addition, student activists critiqued the "arrogance" of white South Africans, who promoted as "superior" their "values, standards and outlook to life", and sought simultaneously to taint and undermine "the dignity and worth" of black South Africans in all areas of their lives. ${ }^{58}$ This, according to Biko, made black South Africans feel less than whites, as he highlighted in a piece entitled "We Blacks" in the September 1970 SASO Newsletter:

... in an effort to destroy completely the structure that had been built up in the African society and to impose imperialism with an unnerving totality the colonialists were not satisfied merely with holding a people in their grip and emptying the Native's brain of all form and content, they turned to the past of the oppressed people and distorted, disfigured and destroyed it. No longer was reference made to African culture, it became barbarism. Africa was the 'dark continent'. ... No wonder the African child learns to hate his heritage in his days at school. So negative is the image presented to him that he tends to find solace only in close identification with the white society. ${ }^{59}$

55. S. Biko, "White Racism and Black Consciousness", in I Write What I Like (HarperCollins, New York, c.1978, 1986), p 61.

56. S. Biko, "Black Souls in White Skins?", in I Write What I Like (HarperCollins, New York, c.1978, 1986), p 20. For more on liberals, see pp 19-26.

57. Biko, "White Racism and Black Consciousness", pp 64-65.

58. Biko, "Black Souls in White Skins?", p 20; and Biko, "White Racism and Black Consciousness", pp 69-71.

59. S. Biko, "We Blacks", in I Write What I Like (HarperCollins, New York, c.1978, 1986), p 29. 
Importantly, according to these activists, this encouraged black South Africans to act submissively towards whites, and to embrace "Western" or "white values" and "norms" if they wanted to get anywhere in life. ${ }^{60}$ To help challenge this, Biko and other student activists promoted the philosophy of Black Consciousness (BC). The "first step", he argued, on the road to the development of an effective "programme designed to change the status quo..." was to recognise how the apartheid system had worked to undermine and oppress the "black man", but also

... to pump back life into his empty shell; to infuse him with pride and dignity, to remind him of his complicity in the crime of allowing himself to be misused and therefore letting evil reign supreme in the country of his birth. This is what we mean by an inward-looking process. This is the definition of 'Black Consciousness'.61

For Biko, an essential part of the Black Consciousness programme was to "correct false images of ourselves in terms of Culture, Education, Religion [and] Economics". For this activist, there was

... always an interplay between the history of a people i.e. the past, and their faith in themselves and hopes for their future. We are aware of the terrible role played by our education and religion in creating amongst us a false understanding of ourselves. We must therefore work out schemes not only to correct this, but further to be our own authorities rather than wait to be reinterpreted by others. ${ }^{62}$

Although these quotations provide just a small sample of these student activists' ideologies, they do give a taste of their narrative constructions, including their reconceptualised ideas about achievement. However, to gain a better understanding of the production, meaning and purposes of their narrative, we need to locate their words within their broader historical context, as we did in the previous section.

The South African Students' Organisation (SASO), from which Black Consciousness ideas initially emerged, developed as a national students' organisation in the late 1960s.63 Formed by a group of black students, who broke away from the National Union of South African Students (NUSAS), SASO was created for several

60. Northwestern University, Chicago (hereafter NWU), The Melville Herskovits Library of African Studies (hereafter MHLAS), EAA8603, "Old Values, Concepts and Systems", 1971, pp 4 and University of the Witwatersrand, Johannesburg (hereafter Wits), South African History Archive (hereafter SAHA), Karis-Gerhart Collection (hereafter KGC): Part III NUSAS, Folder 577, "Information Sheet Number 1/1972: The South African Students Organisation", Attached to a letter circulated by the president of NUSAS to all SRC presidents and various branches of NUSAS, 12 January 1972, pp 2-3.

61. Biko, "We Blacks", pp 28-29.

62. S. Biko, "The Definition of Black Consciousness", in I Write What I Like (HarperCollins, New York, c.1978, 1986), p 52.

63. During the 1970s, SASO's ideas spread beyond universities, influencing the creation of other organisations, such as the Black People's Convention (BPC) and Black Community Programmes (BCP). 
reasons. ${ }^{64}$ Firstly, these students were frustrated by the white-led and reformist nature of NUSAS's multi-racial politics, which they felt did not represent their interests adequately. ${ }^{65}$ Secondly, SASO sought to mobilise students against developments within the country's apartheid-created black universities, which undermined students' rights, as evident in the banning of Students' Representative Councils (SRCs), the imposition of strict curfews, police brutality, and the arrests and detention of students. ${ }^{66}$ Thirdly, these students sought to inspire into action, not only students, but also people from their parents' generation, who had experienced the harsh repressions of the 1950s and early 1960 s, and had, due to fear, stoically accepted their oppressed fate. ${ }^{67}$ Unlike the earlier generations of students who studied at a time when the apartheid government had just come to power, and who had not yet grasped fully the implications of this regime's corrosive effects on black lives, this BC generation, studying some 20 years later, could see the fuller implications and felt betrayed by their elders whom they believed had failed to stand up to apartheid hegemony effectively.

Many of SASO's BC ideas emerged from the minds of students studying medicine in Durban. In 1971, a Wits student highlighted this in a Wits Student newsletter when he wrote: Durban's "UNB is the centre of SASO ..." ${ }^{68}$ Indeed, Steve Biko, a student registered at Durban's medical school from 1966 until 1972, was elected the organisation's first president in July 1969,69 a position he held until July 1970 when he took over as the organisation's publicity director. ${ }^{70}$ In these two positions, he was able, together with other SASO leaders, to formulate and communicate many of this organisation's BC ideas. ${ }^{71}$ SASO's first headquarters was also based in Durban, first in

64. For more on the history of NUSAS, see G.C. Moodie. "The State and the Liberal Universities in South Africa: 1948-90", Higher Education, 27, January 1994, pp 1-40.

65. Biko, "Black Souls in White Skins?", pp 19-26; and Biko, "White Racism and Black Consciousness", pp 3-5.

66. Badat, Black Student Politics, pp 61-75.

67. S. Biko, "Fear - An Important Determinant in South African Politics", in I Write What I Like (HarperCollins, New York, c.1978, 1986), pp 73-79.

68. Wits University Archives (hereafter WUA), Central Records Office (hereafter CRO), Taffy Adler, "University of Natal, Black Medical School”, Wits Student 23, 9, April 1971, $\mathrm{p}$ 9. The UNMS was also commonly referred to at the time as UNB (or the University of Natal's Black Section).

69. S. Biko, "South African Students' Organisation - Its Role, Its Significance and its Future" in I Write What I Like (HarperCollins, New York, c.1978, 1986), pp 3-4. This was Biko's presidential address to the first National Formation School of SASO, held at the UNMS Alan Taylor Residence, 1-4 December 1969.

70. Indeed, most of the chapters published in Biko, I Write What I Like are reproductions of Biko's speeches or writings from the late 1960s and through the 1970s. For more on his writings, see M.V. Mzamane and D.R. Howarth, "Representing Blackness: Steve Biko and the Black Consciousness Movement", in L. Switzer and M. Adhikari (eds), South Africa's Resistance Press: Alternative Voices in the Last Generation under Apartheid (Ohio University Centre for International Studies, Athens: OH, 2000).

71. SASO replaced its leadership annually at its national General Students' Council. For more on the contributions of other SASO leaders, see Pityana et al (eds), Bounds of 
Biko's dorm room at the medical school, and then in the early 1970s at an off-site location - 86 Beatrice Street - which, over the years, involved medical students at the executive level and in supportive roles. ${ }^{72}$

A key reason for medical student involvement in this organisation's foundation years was their university's more protected campus environment, which allowed them to mobilise politically. This stemmed from the University of Natal's less draconian management style compared to the country's black universities at the time, particularly those created after the passage of the 1959 Extension of University Education Act. ${ }^{73}$ Unlike many of these black universities that sought to shut down opportunities for the political mobilisation of their students, the University of Natal allowed its black students to have an SRC, which gave them a voice in university matters and allowed them to participate in NUSAS via their SRC representatives. ${ }^{74}$ Furthermore, they did not have a standing police or army presence on their campus to deter students' political activities, as was the case on other black campuses. ${ }^{75}$

While these students had it better in some ways than their black counterparts at other universities, in other respects, UNMS students suffered a myriad of residential and training hardships, which frustrated and angered them. One set of problems related to the Alan Taylor Residence (ATR), a converted World War Two era military barracks, located about 10 kilometres from the medical school. The university had acquired the ATR on a long-term lease from the government to ensure that it met the country's residential racial zoning laws. ${ }^{76}$ By the late 1960s, about two-thirds of UNMS students were housed in this residence. ${ }^{77}$ Always a bone of contention because of its austere and cramped space, its distance from the medical school, and its location in the noisy and polluted Durban south industrial area of Wentworth, the ATR situation became unbearable for students in the 1970s and 1980s when increased admissions,

Possibility; and T. Sono, Reflections on the Origins of Black Consciousness in South Africa (HSRC, Pretoria, 1993).

72. For more on SASO's links to the UNMS, see Noble, A School of Struggle, particularly chapters 6 and 7.

73. Badat, Black Student Politics, pp 70-75.

74. It was through their membership of this university's Medical Students Representative Council that student representatives, such as Biko, had the budget to affiliate as members and participate in national NUSAS conferences, which ultimately led to the formation of SASO. See Wits SAHA KGC Part I: Interviews, Folder 41, Zuma, Nkosazana Dlamini (conducted by Gail Gerhart in London, 3 July 1988), p 36.

75. SMHSUA MEDUNSA Press Cuttings, 1977-1982, "Students at MEDUNSA Hit Police Action", Star, 1 October 1982; "Baton Charge”, Sowetan, 14 June 1983; V. Mashumi, "No Peace at 'Ethnic' Campus", Pretoria News, 24 June 1983; Badat, Black Student Politics, pp 61-75.

76. UKZNA H6/1/1, Medical School - History, G.W. Gale, "The Story of the Durban Medical School", 25 January 1976, p 18.

77. H.L. Watts, "Black Doctors: An Investigation into Aspects of the Training and Career of Students and Graduates from the Medical School of the University of Natal. Part I: The Students" (Institute for Social Research, University of Natal, Durban, 1975), pp 27-28. 
which had doubled compared to the 1950s period, severely worsened the overcrowding. ${ }^{78}$

Another set of problems related to the racial discrimination they experienced in their teaching environment. This included "abusive" and "racist utterances" produced by some members of staff during lectures and ward rounds, remarks which belittled students' intellectual abilities and "humiliated" them. ${ }^{79}$ In addition, students were forced to endure segregated facilities at their King Edward VIII teaching hospital, ${ }^{80}$ as well as challenging clinical training conditions caused by severe patient overcrowding and staff, supplies and equipment shortages at this "non-European" public hospital. ${ }^{81}$ Although these hardships contributed to the failure of some students, who either had to repeat a course or year (depending on the number of subjects failed in any given year), and caused some to drop-out or be expelled for repeated academic underperformance, these adversities and racialised indignities fuelled other students' discontent and spurred some, such as Biko and other BC activists, into action. ${ }^{82}$

78. UKZNA, MQ 1/1/1-5, "A Response to Gas Smell from Oil-Refinery", The Amoeba, 2, 4, May 1954, p 8; and "Facts you Should Know...", The Amoeba 2, 6, September 1954, p 3; UKZNA C10/6/1-2, "Memorandum on the Need to Increase the Accommodation Available for Medical Students at the Alan Taylor Residence, 1972", UKZNA Board of the Faculty of Medicine minutes, 11,13 and 15 May 1981.

79. Interview with ZM, Durban, 11 September 2003. This doctor preferred to remain anonymous. Others raised similar points, such as Watts, "Black Doctors", p 40; Makgoba, Mokoko, p 34; UKZNA, K.P. Mlisana, "UND Black Section: Personal Reflections", in University of Natal Medical School Reconciliation Graduation Booklet 1995 (Indicator Press, Durban, December 1995), p 11; M. Ramphele, Across Boundaries: The Journey of a South African Woman Leader (Feminist Press, New York, 1995), pp 6970; and Interviews with M.J. Matjila, Durban, 11 July 2003 and B.T. Naidoo, Durban, 15 September 2019.

80. Although King Edward VIII Hospital was designated a "non-European" hospital, it did employ staff, including doctors and nurses of all 'races' and so had racially segregated cafeterias, change-room, toilet and overnight facilities for their black and white staff. See Kuper, An African Bourgeoisie, pp 239-240.

81. By the 1970s, this 2000-bed hospital often went over its capacity, which meant patients slept on floor beds. NRMSMA, File: Hospitals, Natal, King Edward Hospital, "It's no go on Hospital Expansion", Natal Mercury, 29 July 1971; "King Edward's Daily Nightmare”, Daily News, 25 June 1974; "King of Hospitals is Begging for Funds”, Natal Mercury, 25 November 1986; "The War Zone that is King Edward”, Sunday Tribune, 16 August 1987.

82. The highest rates of failure occurred in the preliminary year, but also in second year, because of Physiology (in some years up to $40 \%$ of students). African students failed at a much higher rate than Indian and Coloured students largely because of their poorer Bantu Education backgrounds. For more on this, as well as analysis of other reasons why students under-performed academically, see Noble, A School of Struggle, pp 150151, 155-156, 189-194, 338. 
Similar to the high standards-focused narrative discussed earlier in this article, the narrative created and promoted by BC student activists can also be viewed as a counter-narrative, which was developed to oppose the negative apartheid-era master discourse that cast black students and black South Africans more broadly as inferior. Biko made the case for BC's oppositional stance when he equated it to a Hegelian dialectic:

... since the thesis is white racism there can only be one valid antithesis i.e. a solid black unity to counterbalance the scale. If South Africa is to be a land where black and white live together in harmony without fear of group exploitation, it is only [possible] when these two opposites have interplayed and produced a viable synthesis of ideas and a modus vivendi. We can never wage any struggle without offering a strong counterpoint to the white races that permeate our society so effectively. ${ }^{83}$

Yet, in other ways, the $\mathrm{BC}$ discourse was not exactly the same as the counter-narrative discussed earlier. Firstly, it criticised those promoting the first narrative. Indeed, frustrated by Western-inspired ideologies, these activists not only sought to critique discourses that promoted the view of black South Africans as inferior but also questioned the tactics of those promoting the first narrative, whose efforts to encourage success through attainment of high academic standards, they believed, did not go far enough to challenge the apartheid system. ${ }^{84}$ For them, this narrative promoted the status quo as it accepted or embraced "white standards", in other words, "value systems ... culture ... and outlook to life" as the "norm" or model to emulate if black South Africans wanted to succeed or advance in life. 85

Secondly, beyond critiquing Western notions of success, BC activists produced a more blatantly oppositional and politicised rhetoric, which called on students to denounce the larger systemic apartheid inequalities that undermined black South Africans. ${ }^{86}$ For these activists, the promotion of a narrative focused on high academic achievement placed the burden and pressure unfairly on black students as individuals to succeed (or fail) based on their own efforts despite the mountain of obstacles stacked against them. Certainly, the fact that black and white South Africans did not begin with a level playing field, and that black South Africans had to perform in a system rigged to give white South Africans preferential treatment while imposing impediments that thwarted black aspirations, was a key contention of $\mathrm{BC}$ activists. ${ }^{87}$

83. Biko, "The Definition of Black Consciousness", p 51.

84. S. Biko, "Black Campuses and Current Feelings", in I Write What I Like (HarperCollins, New York, c.1978, 1986), pp 17-18; and University of Fort Hare (hereafter UFH), Centre for Cultural Studies (hereafter CCS), AZAPO/BCM Records, Box 31, "Graduation from Illusions to Disillusion", SASO Bulletin, 1, 1, June 1977, pp 1-2.

85. Biko, "The Definition of Black Consciousness", pp 48-49; and NWU MHLAS EAA8603 SASO, "Old Values, Concepts and Systems", pp 1, 4.

86. S. Biko, "Letter to Students' Representative Council Presidents", in I Write What I Like (HarperCollins, New York, c.1978, 1986), pp 10, 12.

87. Biko, "White Racism and Black Consciousness", pp 60-61. 
To help "boost morale" and "confidence", BC activists sought to counter the pervasive "negative ... images" produced about black South Africans by focusing on "positive" ones that generated a sense of "Black pride". ${ }^{88} \mathrm{~A}$ key issue that Biko and other UNMS's SASO branch executives tackled early in their term of office was the usage, by University of Natal authorities, of disparaging terms such as "non-Europeans" or "nonwhites" to refer to black students. In September 1970, Biko wrote in an article in the SASO Newsletter that use of the term "Black" instead of the other terms signified students' "refus[al] to be regarded as non-persons and claim[ed] the right to be called positively". ${ }^{89}$ After several months of lobbying in 1970, these students won a victory as the university agreed to change its terminology, for example, from "University of Natal Non-European Section" to "University of Natal Black Section" when referring to its medical school in all its official documentation. ${ }^{90}$

They also sought, in their counter-narrative, to reframe achievement in two ways. Firstly, they did this by turning the attention to various black historical, societal and cultural "achievement[s] and capabilities". ${ }^{91}$ They wrote many articles focused on historical and contemporary issues that affected black communities, not only to "conscientise" and inform them about various matters, but also to promote a sense of pride in what they regarded as major black "achievements" in their present and past. ${ }^{92}$ This included discussion, for example, of the ideas of several African decolonisationera leaders, such as Zambia's first independence-era president, Dr Kenneth Kaunda. Further, there was a focus on the thoughts of leading African intellectuals, such as Dr Frantz Fanon, and the accomplishments of past "heroes" who "formed the core of resistance to white invaders", as well as "successful nation build[er]s ... like Chaka, Moshoeshoe and Hintsa". 93

88. Biko, "Letter to Students' Representative Council Presidents", p 15; Biko, "We Blacks", pp 29-30; Biko, "The Definition of Black Consciousness", p 52; and S. Biko, "Some African Cultural Concepts", in I Write What I Like (HarperCollins, New York, c.1978, 1986), p 46.

89. S. Biko, "Who is Black", SASO Newsletter, September 1970, p 2 available online at https://www.sahistory.org.za/archive/saso-newsletter-september-1970 (accessed on 31 August 2019).

90. Ramphele, Across Boundaries, p 55.

91. NWU MHLAS EAA8618 SASO, Letter from Barney Pityana (president of SASO) to SRC presidents (All South African Universities), National Student Organisations, Other Organisations and Overseas Organisations Re: "South African Students' Organisation (SASO)", 1970/1971, p 3.

92. Biko, "White Racism and Black Consciousness", pp 68-69. For more on the varied issues BC-inspired student activists focused on, see: B.A. Khoapa (ed.), Black Review 1972 (Black Community Programmes, Durban, 1973); M.P. Gwala (ed.), Black Review 1973 (Black Community Programmes, Durban, 1974); T. Mbanjwa (ed.), Black Review 1974/1975 (Black Community Programmes, Durban, 1975); S. Biko, "Let's Talk about Bantustans", in I Write What I Like (HarperCollins, New York, c.1978, 1986), pp 80-86; NRMSMA, "UDW - Profile", UNB News, 2, 1979, pp 12-14, "Editorial”, UNB News, 2, 1979, p 3; and "Detentions", UNB News, 1, April 1982, pp 4-6.

93. Biko, "Some African Cultural Concepts", pp 40-47; and Biko, "White Racism and Black Consciousness", pp 66-72. 
Secondly, BC ideology focused on promoting, what adherents saw as the "positive virtues" of "indigenous cultures", such as the "community oriented" approach to life, such as communal land ownership "at the heart" of many "traditional" African societies. ${ }^{94}$ For Biko, a close-knit sense of community offered such societies a less competitive outlook and a more sharing and caring approach to life compared to the competitive, "impersonal" and self-serving "individualism" that was the "hallmark of the [Western] capitalist approach", which "us[ed] people as stepping stones" to progress in life. 95 Drawing on Kaunda's ideas about African "humanism", BC activists promoted an alternative achievement narrative for black South Africans:

It is through cooperation ... that man [sic] will achieve all [of] which he is capable. ... [In a community-focused system] people were valued not for what they could achieve but because they were part of the others. Their contribution [was] ... to the material welfare of the village... [not to] self-satisfaction and individualism ... [where] enrichment was arrived at on the expense and exploitation of others. ${ }^{96}$

Constructing his point about appreciating African values and standards, Biko wrote in his article "We Blacks":

... '[B]lack consciousness' seeks to show black people the value of their own standards and outlook. It urges black people to judge themselves according to these standards and not to be fooled by white society who have white-washed themselves and made white standards the yardstick by which even black people judge each other. ... 'Black consciousness' therefore seeks to give positivity in the outlook of the black people...97

This message was directed mainly at black university students, particularly medical students, whom BC activists felt were becoming too "individualistic" and "elitist" in their views and aspirations, and thus more distanced from their communities because of their exposure to Western values and standards through their many years of education..$^{98}$ As part of their tasks, these activists sought to inspire a stronger sense of connection between university students and their wider communities by encouraging them to get involved in extra-curricular, volunteer community work on weekends and during holiday periods, such as adult literacy programmes and preventive health

94. Biko, "We Blacks", pp 30-31; NWU MHLAS EAA8618 SASO, "Message from SASO”, n/d [early 1970s?], pp 1-2; Biko, "White Racism and Black Consciousness”, pp 9-10.

95. Biko, "Some African Cultural Concepts", pp 41-43; and Biko, "We Blacks", p 30.

96. NWU MHLAS EAA8603 SASO, "Old Values, Concepts and Systems”, pp 3-5, 7.

97. Biko, "We Blacks", p 30.

98. Wits, SAHA KGC, Part III Political Documents Folder 748 SASO, "SASO 1972", Information pamphlet: “The University - What Does it Mean to You?", February 1972; UFH CCS Studies, AZAPO/BCM Records, Box 31. "Graduation from Illusions to Disillusion"; and D. Mji, "Presidential Address to 8th G.C.S", both in SASO Bulletin, 1, 1, June 1977, pp 1-3; SMHSUA MEDUNSA Press Cuttings 1977-1982, "Natal Graduation Boycott", The Post, 20 April 1980. 
work. ${ }^{99}$ Besides giving back and sharing their knowledge, working with individuals and groups to help empower and improve the lives of people in poorer communities, BC activists also hoped that by getting involved in such projects, students would obtain a different sense of achievement by "win[ning] the support and respect of our people" when doing such work. ${ }^{100}$

Undoubtedly, SASO's "Be Black and Proud"-focused narrative did help to conscientise and inspire a more positive mind-set in UNMS students. Malegapuru Makgoba, who was in the same class as Biko, remembered how, during the early 1970s, the school's SASO leaders "were always at meetings campaigning and trying to conscientise us" about being "Black and Proud":

They were very articulate and convincing in their arguments ... We joined as members in droves. ... They read poetry, sang liberation songs, showed banned movies and discussed liberation politics. Even the most virgin of us began to understand the serious nature of our political problems. ... Black Consciousness ... was exciting, stimulating and unifying. ... [Its] leaders gave us pride, hope and things to aspire towards. ${ }^{101}$

Mamphela Ramphele, who started her medical degree in 1968, and later became a leader within in the $\mathrm{BC}$ movement, highlighted memories of her experiences of this organisation's powerful conscientising role:

Natal Medical School ... not only provided me with medical training, but it offered an environment for the transformation of my life from an innocent rural girl to a person who became alive to the vast possibilities which life has to offer. ... I [became] keenly interested in the discussions, which were a political education for me. I learned about the true history of my country, the struggle to resist conquest, and later the struggle for equal rights with those who had conquered us, the stories of heroes of the struggle ... and the role students could and should play to take the struggle forward. ${ }^{102}$

99. Wits, SAHA KGC Part III SASO Folder 746: V. Mafungo, "Some Aspects of Community Development", Report on Seminar on Community Development/Involvement, July 197[?]; Folder 749: "The 'New Farm' Project on Preventive Medicine, 1972"; Folder 750: “Community Development", Reports presented at the 3rd General Students' Council of SASO, St Peter's Seminary, Hammanskraal, 2-9 July 1972; Folder 753: "Community Development", Commissions presented at the 4th General Students' Council of SASO, St Peter's Seminary, Hammanskraal, 14-22 July 1973; Folder 755: "UNB Report to NEC", Reports presented at the Federal Theological Seminary, Alice, 23 to 26 May 1974.

100. NRMSMA, M.M.R. Belle, "From the President's Desk" (Message from the President of the MSRC), UNB News, 2, 1979, pp 17-18. Also see M. Ramphele, "Empowerment and Symbols of Hope", in Pityana et al (eds), Bounds of Possibility, pp 154-178.

101. Makgoba, Mokoko, pp 32-33.

102. Ramphele, Across Boundaries, p 57. For similar views, see Noble, A School of Struggle, pp 209-221. 
Even in the 1980s, after Biko's death in detention and the banning of all BC organisations in the late $1970 \mathrm{~s},{ }^{103}$ BC's positive ideas remained influential at the UNMS. This was because its psychologically-uplifting and empowering message was no less relevant in this period as Mfanyana 'Joe' Ndlovu, a qualified psychiatrist, who studied at the UNMS in the 1980s, highlighted in an interview: "Black Consciousness [made you] ... feel that you [were] worthwhile as a person, you're [were] not inferior as the white people [continued to] tell you". 104 Moreover, although BC organisations were banned by the late 1970s, these organisations had done enough by then, in terms of spreading their message beyond university campuses, to lay the foundations for a defiant anti-apartheid mind-set amongst a broader collective of black South Africans. ${ }^{105}$ Indeed, as several scholars have highlighted in their research, its message had given growing numbers of black South Africans, including UNMS students, the confidence to continue with their struggles into the 1980s and early 1990s, but as part of other organisations, such as the Azanian People's Organisation (AZAPO) and the United Democratic Front (UDF) which came to lead the aboveground anti-apartheid struggle, the latter in alliance with the banned African National Congress which became popular amongst UNMS student activists in this period. ${ }^{106}$

Beyond its positive message, similar to the high standards-focused achievement narrative discussed above, these BC narratives were also exploited to spur students into action in the 1970s and 1980s. Certainly, built into BC's ideology was a call for action - "a programme designed to change the status quo" and to "overhaul the whole system in South Africa" - as the next step on the road to "total emancipation". 107 For BC

103. Biko died in police detention in September 1977 and all BC organisations, including SASO, BCP and BPC were banned a month later. Their leaders were arrested by the apartheid government.

104. Interview with M.J. Ndlovu, Durban, 14 August 2003. This perspective was also highlighted by other doctors who studied at the UNMS. Interviews with B. Maharaj, Durban, 10 June 2003; M. Mashego, Durban, 9 July and 7 October 2003; and M.B. Kistnasamy, Durban, 26 August 2003.

105. Various scholars have shown that by the 1980s, BC's message had filtered out well beyond university campuses. It had spread to influence school-going children, workers' organisations, political organisations, as well as countless civic, religious and other community-based organisations. For more on this, see Gerhart, Black Power in South Africa; B. Hirson, Year of Fire, Year of Ash: The Soweto Revolt: Roots of a Revolution? (Zed Press, London, 1979); T. Lodge, Black Politics in South Africa since 1945 (Longman, London and New York, 1983) and South African Democracy Education Trust (SADET), The Road to Democracy in South Africa: Volume 2, 1970-1980 (UNISA Press, Pretoria, 2006) and Volume 4, 1980-1990 (UNISA Press, Pretoria, 2010).

106. In 1978, AZAPO was formed after BC organisations were banned. It sought to carry forward BC-inspired political ideologies, but became less popular in the 1980s as a shift towards non-racialism in anti-apartheid politics became stronger, led by organisations such as the UDF. See T. Lodge and B. Nasson, All, Here, and Now: Black Politics in South Africa in the 1980s (Ford Foundation and David Philip, Cape Town, 1991). For more on the 1980s era of UNMS students' politics, see Noble, A School of Struggle, pp 262-275.

107. Biko, "White Racism and Black Consciousness", p 65; Biko, "We Blacks", p 29 and NWU MHLAS EAA8603 SASO, "Old Values, Concepts and Systems”, p 1. 
activists, once "liberation from psychological oppression... [or their] inferiority complex" was achieved, then black South Africans, "those who [were] by law or tradition, politically, socially and economically discriminated against as a group in South African society and identifying themselves as [such]", could rally together as allies against their common apartheid oppressors and begin in earnest their "struggle towards the realisation of their aspirations". 108

At the UNMS, the circulation of BC's defiant, identity-affirming narrative gave some students the confidence to question and take action. This was evident at the small-scale level where some individuals stood up to particular lecturers for their "racist" comments or "patronising ways". ${ }^{109}$ It also encouraged some students to act at a larger group level, with boycotts of lectures, protest marches or mass gatherings. These group actions were geared towards disrupting certain functions of the university, to voice opposition to their problems, and/or to pressurise the authorities to implement changes. For example, there were remonstrations against the inferior quality of canteen food, overcrowded residence conditions, the segregated seating at graduation, lack of university transport to and from the medical school, fee increases and the high failure rate in some years, which led to exclusions. ${ }^{110}$ Additionally, group protests took place to challenge broader apartheid era inequalities such as racial discrimination in the country's public hospitals, the expulsion of black student activists from university campuses, police brutality, inequalities in the Bantu Education system, as well as the arrest and deaths in detention of anti-apartheid activists, particularly during various government declared states of emergency. ${ }^{111}$

108. NWU MHLAS FAA 8637 SASO, "Who are the Real Terrorists? A Document of the SASO/BPC Trial" (published and printed by the International University Exchange Fund, January 1977), pp 10-11.

109. Interviews with S.B. Pitsoe, Durban, 17 June 2003, Y.K. Seedat, Durban, 14 July 2003 and V. Wilson, Durban, 6 November 2003. See also Ramphele, Across Boundaries, p 70.

110. See for example: NRMSMA, "Student Reply on Food Boycott", Daily News, 13 August 1970; UKZNA C10/6/1-2, "Memorandum on the Need to Increase the Accommodation Available for Medical Students at the Alan Taylor Residence, 1972"; UKZNA C10/7/1, "Alan Taylor Residence", UN Council Minutes, 18 March 1977, p 215; UKZNA C10/7/1, “Transport for Black Students”, UN Council Minutes, 15 June 1979, p 204; SMHSUA MEDUNSA Press Cuttings 1977-1982: "Natal Graduation Boycott", The Post, 20 April 1980; University of the Western Cape (hereafter UW), Mayibuye Archives Centre (hereafter MAC), Natal 1984, "Natal Medical Students Face 30 per cent Fee Hike", Natal Mercury, 28 October 1983; NRMSMA, "Medical School Students Boycott Lectures”, The Post, 1 February 1984; UKZNA, "Boycott of Fedics Catering Services in the Faculty of Medicine and Alan Taylor Residence”, UN Senate Minutes, 21 May 1986, p 204.

111. See UKZNA, Students' Societies, SASO, "Student Unrest Spreads", Natal Mercury, 12 May 1972; NRMSMA, "Medical School Closes Early", Natal Mercury, 21 June 1976; UKZNA C10/6/1-2, "Death of Mr S. Biko: Students Protest", UN Council Minutes, 16 September 1977, p 37; UKZNA XS 10/1/1-2 Cuttings Medical School, "State Silent as Medical Students Keep Up Boycott", Daily News, 8 October 1977; UKZNA XS 10/1/1-2 Cuttings Medical School, "Medical Students to Continue Boycott", Natal Mercury, 20 June 1980; UKZNA XS 10/1/1-2 Cuttings Medical School, "Ripples from Fort Hare are Lapping on Durban", Daily News, 12 August 1982 and NRMSMA, Letter from P. Naidoo (MSRC 
However, while SASO's "Black pride" narrative did help to conscientise and empower some UNMS students, its message did not appeal to all students on the campus in the 1970s and 1980s. Although it is impossible to determine the exact number of UNMS students who became active SASO members, a testament to the lack of existing historical records on this issue, support for SASO's calls to action was rarely taken up by all students at this campus. ${ }^{112}$ Certainly, official University of Natal investigations into student intimidation during boycotts demonstrates this point. ${ }^{113}$ The reasons for this are varied. Some students did not want to involve themselves in political matters, choosing rather to focus on their studies. ${ }^{114}$ Indeed, a strong enticement to graduate were the opportunities it offered to improve students' socioeconomic position through attainment of professional status and financial rewards. Others did not identify with BC's message. For example, some Indian and Coloured students felt their interests were less represented by SASO, which they felt prioritised African cultural values and interests, while others worried about the organisation's anti-white stance. ${ }^{115}$ Still others felt alienated by its masculine gender bias. To be sure, male students dominated its leadership positions and rarely mentioned women's particular concerns. ${ }^{116}$ Even the language used by its leaders to describe the condition

President) to S. Kallichurum (Dean), 26 July 1985; UKZNA C10/9/2 "State of Emergency", UN Council Minutes, 15 August 1986, p 260.

112. In addition to police raids of SASO offices, which led to the confiscation of records, it was dangerous to keep membership records, which the police could use to identify and arrest activists. In his research on student protests in the 1970s, Hirson estimated that black students in universities across South Africa in the early 1970s numbered 9000 students and that SASO claimed student support (based on SASO Newsletter sales) of between 4000 and 6000 students. Extrapolating from Hirson's figures, SASO membership at the UNMS in this period was thus likely about half (possibly a bit more) of the total student body of roughly 500 to 600 students at the time. See Hirson, Year of Fire, Year of Ash, pp 86, 108.

113. UKZN Board of the Faculty of Medicine Minutes, 29 May 1980, 17 August 1984 and 7 October 1985; UKZNA C10/9/1, "Intimidation of Students in the Medical School", UN Council minutes, 16 November 1984; "Inquiry into Intimidation of Students by the MSRC", UN Senate minutes, 21 November 1984 and "Alleged Intimidation of Students in the Faculty of Medicine", UN Council minutes, 17 May 1985.

114. UFH, CCS, AZAPO/BCM Records, Box 31. "Presidential Address to 8th G.C.S" by Diliza Mji, SASO Bulletin, 1, 1, June 1977, p 2-3. For more on this, see Noble, A School of Struggle, pp 221-225.

115. K. Moodley, "The Continued Impact of Black Consciousness", in Pityana et al (eds), Bounds of Possibility, pp 145-146; Interview with V. Wilson, Durban, 6 November 2003; M.V. Mzamane, B. Maaba and N. Biko, "The Black Consciousness Movement", in SADET, The Road to Democracy in South Africa: Volume 2, p 113; Sono, Reflections on the Origins of Black Consciousness in South Africa, p 65; Badat, Black Student Politics, p 86; S. Buthelezi, "The Emergence of Black Consciousness: An Historical Appraisal”, in Pityana et al (eds), Bounds of Possibility, pp 115-116, 124; and Ramphele, Across Boundaries, pp 55-56.

116. M. Ramphele, "'The Dynamics of Gender within Black Consciousness Organisations: A Personal View", in Pityana et al (eds), Bounds of Possibility, pp 214-227; and D.R. Magaziner, "Pieces of a (Wo)man: Feminism, Gender and Adulthood in Black Consciousness, 1968-77", JSAS, 37, 1, March 2011, pp 45-61. 
and solutions for oppressed people were rendered in masculine terms. ${ }^{117}$ Lastly, involvement in anti-apartheid politics was "a dangerous game in those days". 118 In addition to distracting students from their academic work, which led to university exclusions, assaults at the hands of the security police, as well as harassment, arrests and detentions, had serious effects on students' personal safety. ${ }^{119}$

\section{Overlapping and hybrid achievement counter-narratives}

While the previous sections examined the construction of and variances that emerged between two counter-narratives developed by staff and students at the UNMS, this final section complicates things further by reflecting on the issue of overlap and blending that occurred between these two narratives.

An important period of overlap transpired between these two narratives from the late 1960s and arguably through into the 1980s, because of the continued influence of the $\mathrm{BC}$ message on the mind-sets of black South Africans, even though BC organisations had been banned. As quotations from sections 1 and 2 of this article suggest, during this period, different people at the UNMS constructed and promoted both the academic standards-focused achievement narrative and the defiant and positive "Black pride"-inspired narrative. Certainly, construction and promotion of the one counter-narrative at this school did not eliminate the possibility of the existence of the other. They could and did occur simultaneously.

More than this, analysis of these two narratives suggests that sometimes ideas from one achievement counter-narrative could, at certain historical moments, not only overlap with, but also lead to an amalgam of elements from both narratives. A good example is the narrative fashioned in the latter half of the 1970s, when the UNMS was informed about the state's decision in December 1975, to "phase-out" black students from the institution. ${ }^{120}$ This plan entailed sending these students to study medicine at "their own" black universities, which were either being adapted (if they already

117. Biko, "We Blacks", pp 28-29 and Biko, "What is Black Consciousness", pp 99-115. See also P.D. Gqola, "Contradictory Locations: Black Women and the Discourse of the Black Consciousness Movement (BCM) in South Africa", Meridians: Feminism, Race, and Transnationalism, 2, 1, 2001, pp 130-152.

118. Interview with H.J. Coovadia, Durban, 24 June 2003.

119. UKZNA C10/8/1, "Natal Medical Students May Lose Bursaries", Rand Daily Mail, 24 October 1977 and UWC, MAC, Natal, 1984, "Students who 'Flunked' Sparked Off Action: Backgrounder to Medical School Boycott and Closure", The Leader, 10 February 1984; NRMSMA, "Six Students Detained", Daily News, 27 March 1973, "87 Students on Act Charges", n/p, 24 June 1976; "Students in Detention', University of Natal Faculty of Medicine Board Minutes, 13 March 1978; UWC MAC Natal 1985, "Two Students held after Demo", Natal Witness, 30 July 1985; UWC, MAC H36 Natal, 1986, "Shots at Student Demo", Natal Mercury, 13 June 1986.

120. CC EGM File 463/7/3 KCM 56990 (88), "Black Medical School will Go White", Natal Mercury, 17 December 1975. 
existed),121 or built (such as the African Medical University of South Africa or MEDUNSA), ${ }^{122}$ to provide medical training facilities for them. The state's phase-out plan led to much opposition from the school's staff, but particularly its students, who embarked, in September and October 1977, on a prolonged boycott of classes involving the entire student body. ${ }^{123}$

During this 1976/1977 period, both the school's staff and its students, including SASO activists, constructed narratives that sought to counter the state's phase-out plan using arguments that praised the high standards of their institution. Although the promotion of an achievement narrative focusing on high academic standards had been popular amongst staff and some students at the UNMS for some time prior to this period, ${ }^{124}$ this focus was new for SASO student activists. For example, in 1976, at the beginning of their oppositional campaign against the phase-out, a daily newspaper captured how students "with raised fists symbolising Black Power" (a key symbol of SASO's BC movement) protested against the state's plan by lauding the school's past "achievements", particularly the training of hundreds of black doctors. ${ }^{125}$ Similar narratives highlighting "pride" in the institution for its "highest clinical and medical

121. The creation of medical schools at the "Indian" University of Durban Westville (UDW) and the "Coloured" University of the Western Cape (UWC) never materialised. Instead, UWC established a dental school and UDW became a hub for the training of allied health professionals. See G.C. Oosthuizen, A.A. Clifford-Vaughan, A.L. Behr and G.A. Rauche, Challenge to a South African University: The University of Durban-Westville (Oxford University Press, Cape Town, 1981), pp 110-114; UWC, MAC, Medical Schools, "UWC Looks Forward to Training Doctors", Cape Times, 3 December 1975.

122. MEDUNSA was opened in 1978 in the "Bantustan" or African "homeland" of Bophuthatswana and sought to train a variety of African health professionals, including doctors, dentists, veterinarians, nurses and supplementary health workers. See UWC, MAC MEDUNSA 1984, "MEDUNSA - Where Medical History is in the Making", Citizen, 1 February 1978; and F.P. Retief, "The Medical University of Southern Africa after Five Years", SAMJ, 27 November 1982.

123. Although UNMS received a brief reprieve from implementing this plan in 1976 because of delays in the provision of alternative medical facilities, the University of Natal was notified in 1977 that it was to begin the phase-out in 1978. See UKZNA C205/1/1-3, "A Reprieve for Black Medical Course", Natal Mercury, 7 August 1976; and NRMSMA, "Report of the Faculty of Medicine: 1977", 20 June 1978.

124. Professor Reid's narrative, quoted on page 5 of this article, was written in 1976, and focused on his opposition to the state's phase-out plan. For similar staff narrative examples, see WUA CRO Box no. 00886 File no 3 File detail B19/3, "Memorandum on the Need for the Maintenance of Training of Bantu Medical Students at the University of Natal" from the University of Natal's Vice-Chancellor to Col. S.C. Smith (for Admin Circulation), 17 February 1976, pp 1, 4; NRMSMA, "University Fights for its Blacks", Natal Mercury, 24 February 1976; "To the Editor: Signed by 17 Professors of the Faculty of Medicine, UN, Durban re Phasing Out of Admissions of Non-White Students to University of Natal Medical School", SAMJ, 21 February 1976, p 235; SMHSUA MEDUNSA Press Cuttings, 1977-82; "Varsity to Tackle Koornhof on Black Students", Pretoria News, 17 October 1977.

125. UWC MAC Medical Schools, "Black Students in Protest", Natal Mercury, 28 February 1976. 
standards", which had led them to protest against this apartheid move, were constructed by numerous student activists in 1976 and 1977.126

In addition, as part of their protest action, the students actively questioned the standards of the black universities where they were destined to study. Highlighted in documents from the time and interviews from later years, graduates from the UNMS remembered viewing the formation of MEDUNSA as a "bush college", "an apartheid baby", and "an inferior institution".127 In an interview a graduate even told me how students referred to this institution as:

HERBUNSA - the Herbal University of South Africa ... [as] we felt that it was of lower standard ... it was going to be [focused on] herbal medicine, which is the way I think we were socialised that herbal medicine was inferior to Western medicine. But that's how students expressed it. ${ }^{128}$

These concerns were not baseless. In addition to developing in a country with a long history of promoting inferior standards for black South Africans, they surfaced in the wake of public discussions about the possibility of creating a shortened medical training programme for Africans to help alleviate the African doctor shortage in the Bantustans. ${ }^{129}$ The fact that MEDUNSA was prepared to accept students with lower entrance qualifications in maths and science, did not help its public image either, despite assurances that its graduates would meet the minimum degree requirements laid down by the SAMDC because of its carefully developed remedial academic support programme. ${ }^{130}$

126. For similar oppositional statements from black medical students and graduates highlighting their "pride" in their institution because of its "highest clinical and medical standards" and anger which led to protests to challenge apartheid, see for example: "To the Editor, signed by H.N. Desai, Secretary, Medical Graduates Association, UN, Durban re Twenty-Fifth Anniversary Tragedy", SAMJ, 13 March 1976, p 423; UKZNA XS 10/1/1-2, "State Silent as Medical Students Keep Up Boycott', Daily News, 8 October 1977; "Campaign goes on to Save Medical School", Daily News, 12 October 1977; "Second Time Round...", Cape Argus, 21 October 1977; and NRMSMA, "Phasing-Out", MSRC Bulletin, Special Edition, May 1982, 1.

127. See SMHSUA, MEDUNSA Press Cuttings, 1977-1982: F. Khashane, "The 'University in the Bush' Presses on Regardless", Pace, June 1981, pp 58-60; SMHSUA, MEDUNSA 1989, G. Mokae, "Prof Rides the 'White Elephant' to Glory', Pace, April 1988, pp 61-63; Interviews with S.B. Pitsoe, Durban, 17 July 2003, M.J. Ndlovu, Durban, 14 August 2003, Y.K. Seedat, Durban, 14 July 2003, and M.J. Matjila, Durban, 18 July 2003.

128. Interview with MM, Durban, 28 July 2003. This doctor chose to remain anonymous.

129. NRMSMA, Education: Medical, '“Crash' Medical Course: Plan to Beat African Doctor Shortage”, Daily News, 21 August 1971; “Train More Africans': Doctor Shortage”, Daily News, 24 March 1973, and C. Searle, "The Second-Class Doctor and Medical Assistant in South Africa", SAMJ, 31 March 1973.

130. Interestingly, a narrative emphasising achievement of high academic standards and "pride" in MEDUNSA's accomplishments was constructed by those who worked at MEDUNSA during the 1980s and 1990s. See for example: SMHSUA, "From the Rector's Office: Academic Standards", Newsletter to MEDUNSA Students, October 1985, pp 2-3 and SMHSUA, "MEDUNSA - The Background", MEDUNSA Yearbook 1994/95, p 11. 
UNMS student activists at this time thus combined elements of a standardsfocused achievement narrative and a defiant BC-inspired narrative to make their case to counter the state's phase-out plan and eventually the state was forced to abandon it. A protracted boycott to the end of the year would have resulted in the failure of all medical students that year, including 94 final year students who were scheduled to start work as interns in the state's black public hospitals the following year. This forced the government's hand. ${ }^{131}$

Ironically, in the construction of a narrative, student activists who focused on MEDUNSA's inferiority were producing a similar narrative to the one that earlier generations of staff and students had sought to counter with their high standardsfocused narrative when the UNMS first opened. In addition, the development of a hybrid counter-narrative during this protest period highlighted the impact of BC's attack on Western ideologies and models at this time, if not its limits. The deeply ingrained beliefs about the superiority of Western standards were not easily eradicated from the minds of black medical students, who in this instance continued to promote the high standards of their school and questioned anything that deviated from this norm.

Another example of a blend of counter-narrative elements is evident in the early to mid-1990s in the University of Natal's institutional publications produced by academic staff. During this period leading up to the transition to democracy, there are examples of narratives produced about the UNMS that stressed both a celebration of this school's "academic performance", "high standards" and/or "excellence", as well as "pride" in its black alumni's "achievements", which included being "a significant barometer of black politics in this country" and producing many leaders who were "in the forefront of the struggle for political freedom in South Africa". ${ }^{132}$ Sometimes these institutional documents include explicit mention of examples such as Steve Biko, Mamphela Ramphele and Nkosazana Dlamini Zuma. ${ }^{133}$

131. Widespread public pressure also encouraged the state to abandon its plan. SMHSUA MEDUNSA Press Cuttings, 1977-1982, "Doctor Shortage if Black Students Boycott Exams", Weekend World, 16 October 1977; UWC MAC Medical Schools, "Medical Exams Put Off”, The World, 18 October 1977; and "Koornhof Backtracks on Blacks", Rand Daily Mail, 21 October 1977.

132. See for example, UKZNA, "History" and "Messages: Dr U.G. Lalloo, President, MGA" both in P. Duminy and A. Mason, The University of Natal Medical School, 1951-1991: Meeting the Challenge of Change (Faculty of Medicine, University of Natal: Brochure to mark the 40th Anniversary, 1991), p 6; UKZNA "40 Years of Excellence", NU Focus, 2, 2, Autumn 1991, p 18; UKZNA, S. Moodley (Vice-President, Medical Graduates Association), "Echoes from the Past"; and M.M.R. Belle, "Reflections on Life at the Medical School, University of Natal Medical School Reconciliation Graduation Booklet, pp 7-8, 13.

133. NRMSMA, "45 Years of Excellence", University of Natal Medical School (pamphlet), 1995. 
Similar to the earlier mentioned 1970s phase-out era narrative, this institutional narrative illustrated moments of malleability in the construction, by staff (several of whom were black graduates who had taken up appointments at this medical school), of achievement counter-narratives as their producers changed and/or moved through time and sought, in changing historical circumstances, to produce more complex, sometimes melded narratives to counter the apartheid regime more effectively or to align themselves better with changing historical realities.

\section{Conclusion}

This article has examined the construction and dissemination of two particular achievement narratives - one focused on high academic standards, the other on a BCinspired "Black pride" - that were produced by academic staff and students and SASO student activists at the UNMS, South Africa's first apartheid-era black medical school in the highly racialised context of the 1950s to the early 1990s. While quite different in terms of their producers, and the periods of origin and reasons for their emergence, this article argues that both these narratives developed with a similar purpose: as counter-narratives. In other words, they intended to critique or challenge, in their own respective ways, the pervasive and disparaging apartheid-era discourse that portrayed black South Africans as subordinate. Indeed, both these narratives sought to enable those producing them to reframe the dominant discourse, to offer alternatives and more affirming views, and to take an oppositional stance. Yet, although both developed as counter-narratives, they did so with different emphases, highlighting the complexity of these narratives.

Firstly, these counter-narratives produced different understandings of achievement. This article examines the contested nature of achievement because what achievement meant was not the same for everyone in this historical context. While the first narrative promoted the attainment of Western (particularly European) scientific medical models and standards as the foundation for success at the UNMS, and the best way to challenge apartheid naysayers, the second narrative promoted success by focusing on "Black pride". BC student activists, frustrated by Western discourses and models, constructed and promoted in their writings and speeches their own scripts of success to counter those lauded by whites or Westerners, giving students alternative notions of achievement to aspire towards. For these activists, it was only once they had helped black South Africans to re-imagine achievement by promoting a positive mindset and confidence in their own and their societies' abilities and accomplishments, that they would be emboldened to launch a strong challenge to their apartheid oppressors.

Secondly, these narratives exhibited differences in terms of the extent to which their producers were prepared to go to challenge apartheid. Undoubtedly, those who constructed the $\mathrm{BC}$ narrative sought to critique both whose who rendered black South Africans as inferior and also questioned the tactics of those promoting the first narrative, namely those whose efforts to achieve high Western standards, they believed, did not go far enough to challenge the apartheid system. For these activists, 
the first narrative promoted the status quo. Any efforts to mobilise occurred primarily to oppose the depreciation of standards in the medical educational sphere. In addition, they argued that this narrative, based on liberal assumptions, placed the burden or responsibility unfairly on the shoulders of individuals to perform (or fail) through their own hard work, while pushing under the carpet the broader racialised structural inequalities that made it difficult for black South Africans to succeed in the first place. Critiquing Western notions of success and larger systemic apartheid discriminations, $\mathrm{BC}$ activists produced a more blatantly oppositional and politicised rhetoric, which called upon students to get involved in something bigger than the pursuit of their individual career aspirations. Over time, this helped to inspire many students and empowered some to challenge overtly for change by actively protesting in the 1970s and 1980s against various university and broader apartheid policy inequalities that oppressed them.

Yet, while the $\mathrm{BC}$ activists' counter-narratives might have gone further than the high standards-focused ones to challenge apartheid, indeed, successfully disrupting and subverting at particular moments racist stereotyping and the established order, they too had limitations. Certainly, as highlighted in this article, promotion of these BC narratives did not mean acceptance by all. Many students, for a variety of reasons, did not feel they identified with the BC message, which fractured student politics, while others questioned the dangers of engaging in anti-apartheid protest activities, as well as the disruptions, sometimes deleterious, which these activities brought to their studies, and thus future career aspirations. ${ }^{134}$ In addition, looking at BC's influence at the UNMS in hindsight, we can see too that while its narrative critiqued Westerninspired ideologies, its narrative had limited impact in terms of undermining the school's Western-inspired medical educational approach. Indeed, by the end of the apartheid era, this teaching approach remained the dominant one at the UNMS. ${ }^{135}$

Another complexity analysed in this article is the issue of overlap. While these two achievement counter-narratives could sometimes overlap in time; in other words, the construction and promotion of one narrative did not eliminate the possibility or presence of another running parallel to it, there is also evidence that people at the UNMS, at particular historical moments, could develop hybridised achievement counter-narratives with an amalgam of content elements from both narratives. This demonstrated that change was possible in these narrative constructions with the passing of time. Sometimes, an amalgam of elements from more than one narrative produced a stronger argument for their producers to make a case for their causes, or

134. Biko is a good example of a person who was excluded from the UNMS in 1972 for "poor academic performance". Eventually, his political work led to his arrest and detention, and his untimely death in September 1977. See A. Stubbs, "Martyr of Hope: A Personal Memoir", in I Write What I Like (HarperCollins, New York, c.1978, 1986), p 160.

135. UKZNA, "Education", in Duminy and Mason, The University of Natal Medical School 1951-1991, p 11. It was stated in this brochure that: "The basic medical degree course, which extends over six years, conforms to the British model, and remains under the constant scrutiny of a vigilant curriculum committee to ensure the maintenance of the correct balance of its essential components". 
enabled them to align their aims better with the changing historical circumstances in which they found themselves.

Inspired by a poststructuralist approach, this article sought to examine how achievement narratives, produced by particular people, with specific purposes, in South Africa's apartheid-era medical educational environment, were not objective or neutral "facts", but were complex and contested historical formations that gave meaning to people's lives. Understanding the constructed nature of narratives and interrogating how, when and why they emerged, and what effects they had on those who worked and studied at the University of Natal's Medical School provides another layer of analysis, offering further insight into understanding the history of this particular institution.

\section{REFERENCES}

Abbott, P.H., The Cambridge Introduction to Narrative (Cambridge University Press, Cambridge, UK, 2008).

Badat, S., Black Student Politics: Higher Education and Apartheid, from SASO to SANSCO, 1968-1990 (Routledge, New York and London, 1999).

Bamberg, M. and Andrews, M. (eds), Considering Counter-Narratives: Narrating, Resisting, Making Sense (John Benjamins, Amsterdam, 2004).

Beinart, W. and Dubow, S. (eds), Segregation and Apartheid in Twentieth Century South Africa (Routledge, London and New York, 1995).

Biko, S., "Black Campuses and Current Feelings", in I Write What I Like (HarperCollins, New York, c.1978, 1986).

Biko, S., "Black Souls in White Skins?", in I Write What I Like (HarperCollins, New York, c.1978, 1986).

Biko, S., "Fear - An Important Determinant in South African Politics", in I Write What I Like (HarperCollins, New York, c.1978, 1986).

Biko, S., "Let's Talk about Bantustans", in I Write What I Like (HarperCollins, New York, c.1978, 1986).

Biko, S., "Letter to Students' Representative Council Presidents", in I Write What I Like (HarperCollins, New York, c.1978, 1986).

Biko, S., "Some African Cultural Concepts", in I Write What I Like (HarperCollins, New York, c.1978, 1986).

Biko, S., "South African Students' Organisation: Its Role, Its Significance and its Future”, in I Write What I Like (HarperCollins, New York, c.1978, 1986).

Biko, S., "The Definition of Black Consciousness", in I Write What I Like (HarperCollins, New York, c.1978, 1986).

Biko, S., "We Blacks", in I Write What I Like (HarperCollins, New York, c.1978, 1986).

Biko, S., "White Racism and Black Consciousness", in I Write What I Like (HarperCollins, New York, c.1978, 1986).

Booysen, P. de V., "Message from the Vice-Chancellor and Principal of the University of Natal", South African Medical Journal (23 November 1985). 
Brookes, E.H., A History of the University of Natal (University of Natal Press, Pietermaritzburg, 1966).

Buthelezi, S., "The Emergence of Black Consciousness: An Historical Appraisal", in Pityana, B., Ramphele, M., Mpumlwana, M. and Wilson, L. (eds), Bounds of Possibility: The Legacy of Steve Biko and Black Consciousness (David Philip and Zed Books, Cape Town and London, 1991).

Christie, P. and Collins, C., "Bantu Education: Apartheid Ideology and Labour Reproduction", in Kallaway, K. (ed.), Apartheid and Education (Ravan Press, Johannesburg, 1984).

Cohen, D.W., The Combing of History (University of Chicago Press, Chicago and London, 1994).

Cuadraz, G.H., "Myths and the 'Politics of Exceptionality': Interpreting Chicana/o Narratives of Achievement", The Oral History Review, 33, 1 (2006).

Desai, H.N., "To the Editor re Twenty-Fifth Anniversary Tragedy", South African Medical Journal, (13 March 1976).

Digby, A., "Introduction", in Digby, A. and Phillips, H., with Deacon, H. and Thomson, K., At the Heart of Healing: Groote Schuur Hospital 1938-2008 (Jacana, Auckland Park, 2008).

Dubow, S., Scientific Racism in Modern South Africa (Cambridge University Press, Cambridge, 1995).

Ford, D.Y. and Harris, J.J., "The American Achievement Ideology and Achievement Differentials among Preadolescent Gifted and Nongifted African American Males and Females", Journal of Negro Education, 61, 1 (1992).

Gabriel, Y., "Narratives and Stories in Organisational Life", in A. de Fina and A. Georgakopoulou (eds), The Handbook of Narrative Analysis. (Wiley, Chichester, 2015).

Gale, G.W., "Medical Schools in Africa: A Short and Contemporary Survey", Journal of Medical Education, 34, 8 (August 1959).

Gerhart, G.M., Black Power in South Africa: The Evolution of an Ideology (University of California Press, Los Angeles, 1978).

Gish, S., Alfred B. Xuma: African, American, South African (Macmillan Press, London, 2000).

Goonam, K., Coolie Doctor: An Autobiography (Madiba Publications, Durban, 1991).

Gordon, I., Further Report on the Government's Intention to Remove the Faculty of Medicine from the University of Natal (Hayne \& Gibson, Durban, 4 May 1957).

Gordon, I., "Medical Education in the Republic of South Africa", Journal of Medical Education, 37 (September 1962).

Gordon, I., Report on the Government's Intended Action to Remove the Faculty of Medicine from the University of Natal (Hayne \& Gibson, Durban, 4 March 1957).

Gordon, I., Third Report on the Government's Intention to Remove the Faculty of Medicine from the University of Natal (Process Printers, Durban, 25 February 1958).

Gqola, P.D., "Contradictory Locations: Black Women and the Discourse of the Black Consciousness Movement (BCM) in South Africa", Meridians: Feminism, Race, and Transnationalism, 2, 1 (2001).

Gwala, M.P. (ed.), Black Review 1973 (Black Community Programmes, Durban, 1974). 
Harper, S.R., "Niggers No More: A Critical Race Counternarrative on Black Male Student Achievement at Predominantly White Colleges and Universities, International Journal of Qualitative Studies in Education, 22, 6 (2009).

Hirson, B., Year of Fire, Year of Ash: The Soweto Revolt: Roots of a Revolution? (Zed Press, London, 1979).

Hofmeyr, I., "We Spend our Years as a Tale that is Told": Oral Historical Narrative in a South African Chiefdom (Heinemann, Portsmouth: NH, Wits University Press, Johannesburg and James Currey, London, 1993).

Hunt, L. (ed.), The New Cultural History (University of California Press, Berkeley, 1989). Hyvarinen, M., "Analysing Narratives and Story-Telling”, in P. Alasuutari, L. Bickman and J. Brannen (eds), The Sage Handbook of Social Research Methods (Sage, Thousand Oaks, 2008).

Khoapa, B.A. (ed.), Black Review 1972 (Black Community Programmes, Durban, 1973). Kuper, L., An African Bourgeoisie: Race, Class, and Politics in South Africa (Yale University Press, New Haven: CT and London, 1965).

Linde, C., "Narrative in Institutions", in D. Shiffrin, D. Tannen and H. Hamilton (eds), The Handbook of Discourse Analysis (Wiley-Blackwell, Oxford, 2003).

Little, J., Against Meritocracy: Culture, Power and Myths of Mobility (Routledge, London and New York, 2018).

Lodge, T. and Nasson, B., All, Here, and Now: Black Politics in South Africa in the 1980s (Ford Foundation and David Philip, Cape Town, 1991).

Lodge, T., Black Politics in South Africa since 1945 (Longman, London and New York, 1983).

Louw, J.H., In the Shadow of Table Mountain: A History of the University of Cape Town Medical School and its Associated Teaching Hospitals up to 1950, with Glimpses into the Future (Struik, Cape Town, 1969).

Lundholt, M.W., Maagaard, C.A. and Piekut, A., "Counter-Narratives", Wiley Online Library, 21 June 2018, https://onlinelibrary.wiley.com/doi/full/ 10.1002/9781119010722.iesc0201 (accessed on 20 September 2020).

Magaziner, D.R., The Law and the Prophets: Black Consciousness in South Africa, 196877 (Jacana, Johannesburg, 2010).

Magaziner, D.R., "Pieces of a (Wo)man: Feminism, Gender and Adulthood in Black Consciousness, 1968-77", Journal of Southern African Studies, 37, 1 (March 2011).

Makgoba, M.W., Mokoko: The Makgoba Affair: A Reflection on Transformation (Vivlia Publishers, Florida).

Mbanjwa, T. (ed.), Black Review 1974/1975 (Black Community Programmes, Durban, 1975).

McClelland, D.C., The Achieving Society (D. van Nostrand Company, New York, 1976).

McQueen, I.M., Black Consciousness and Progressive Movements under Apartheid (University of KwaZulu-Natal Press, Pietermaritzburg, 2018).

Moodie. G.C., "The State and the Liberal Universities in South Africa: 1948-90", Higher Education, 27 (January 1994).

Moodley, K., "The Continued Impact of Black Consciousness", in Pityana, B., Ramphele, M., Mpumlwana, M. and Wilson, L. (eds), Bounds of Possibility: The Legacy of Steve Biko and Black Consciousness (David Philip and Zed Books, Cape Town and London, 1991). 
Murray, B.K., “Wits as an 'Open' University 1939 -1959: Black Admissions to the University of the Witwatersrand", Journal of Southern African Studies, 16, 4 (1990).

Murray, B.K., Wits the Early Years: A History of the University of the Witwatersrand Johannesburg and its Precursors, $1896-1939$ (Wits University Press, Johannesburg, 1982).

Mzamane, M.V. and Howarth, D.R., "Representing Blackness: Steve Biko and the Black Consciousness Movement" in Switzer, L. and Adhikari, M. (eds), South Africa's Resistance Press: Alternative Voices in the Last Generation under Apartheid (Ohio University Centre for International Studies, Athens: OH, 2000).

Mzamane, V.M., Maaba, B. and Biko, N., "The Black Consciousness Movement", in South African Democracy Education Trust (SADET), The Road to Democracy in South Africa: Volume 2, 1970-1980 (UNISA Press, Pretoria, 2006).

Noble, V., "A Medical Education with a Difference: A History of the Training of Black Student Doctors in Social, Preventive and Community-oriented Primary Health Care at the University of Natal Medical School, 1940s-1960", South African Historical Journal, 61, 3 (2009).

Noble, V., A School of Struggle: Durban's Medical School and the Education of Black Doctors in South Africa (University of KwaZulu-Natal Press, Pietermaritzburg, 2013).

Novick, P., That Noble Dream: The "Objectivity Question" and the American Historical Profession (Cambridge University Press, Cambridge and New York, 1988).

Oosthuizen, G.C, Clifford-Vaughan, A.A., Behr, A.L. and Rauche, G.A., Challenge to a South African University: The University of Durban-Westville (Oxford University Press, Cape Town, 1981).

Parle, J. and Noble, V., The People's Hospital: A History of McCords, Durban, 1890 -1970s (Natal Society Foundation, Pietermaritzburg, 2017).

Phillips, H., The University of Cape Town, 1918 -48: The Formative Years (UCT Press, Cape Town, 1993).

Pillay, V.K.G., "Some Thoughts on Intern Training", South African Medical Journal (2 December 1961).

Pirker, E.U., Hericks, K. and Mbali, M.M. (eds), Forward, Upward, Onward? Narratives of Achievement in African and Afroeuropean Contexts (HHU Books, Dusseldorf, 2020).

Pityana, B., Ramphele, M., Mpumlwana, M. and Wilson, L. (eds), Bounds of Possibility: The Legacy of Steve Biko and Black Consciousness (David Philip and Zed Books, Cape Town and London, 1991).

Portelli, A., The Death of Luigi Trastulli and Other Stories: Form and Meaning in Oral History (State University of New York Press, New York, 1991).

Posel, D., The Making of Apartheid, 1948-61: Conflict and Compromise (Clarendon Press, Oxford, 1991).

Ramphele, M., Across Boundaries: The Journey of a South African Woman Leader (Feminist Press, New York, 1995).

Ramphele, M., "Empowerment and Symbols of Hope", in Pityana, B., Ramphele, M., Mpumlwana, M. and Wilson, L. (eds), Bounds of Possibility: The Legacy of Steve 
Biko and Black Consciousness (David Philip and Zed Books, Cape Town and London, 1991).

Ramphele, M., "'The Dynamics of Gender within Black Consciousness Organisations: A Personal View", in Pityana, B., Ramphele, M., Mpumlwana, M. and Wilson, L. (eds), Bounds of Possibility: The Legacy of Steve Biko and Black Consciousness (David Philip and Zed Books, Cape Town and London, 1991).

"Reference Terms: Western World", https://www.sciencedaily.com/terms/ western_world.htm (accessed on 15 September 2020).

Retief, F.P., "The Medical University of Southern Africa after Five Years", South African Medical Journal, (27 November 1982).

Shapiro, K.A., "Doctors or Medical Aids? The Debate over the Training of Black Medical Personnel for the Rural Black Population in South Africa in the 1920s and 1930s", Journal of Southern African Studies, 13, 2 (1987).

Solórzano, D.G. and Yosso, T.J., "Critical Race Methodology: Counter-Storytelling as an Analytical Framework for Educational Research", Qualitative Inquiry, 8, 1 (2002).

Sono, T., Reflections on the Origins of Black Consciousness in South Africa (HSRC, Pretoria, 1993).

South African Democracy Education Trust (SADET), The Road to Democracy in South Africa: Volume 2, 1970 -1980 (UNISA Press, Pretoria, 2006).

South African Democracy Education Trust (SADET), The Road to Democracy in South Africa: Volume 4, 1980 -1990. (UNISA Press, Pretoria, 2010).

Stubbs, A., "Martyr of Hope: A Personal Memoir", in Biko, S., I Write What I Like (HarperCollins, New York, c.1978, 1986).

“The Durban Medical School: A Progress Report”, South African Medical Journal, (7 May 1955).

"To the Editor: Signed by 17 Professors of the Faculty of Medicine, UN, Durban re Phasing Out of Admissions of Non-White Students to University of Natal Medical School", South African Medical Journal, (21 February 1976).

"To the Editor, signed by H.N. Desai, Secretary, Medical Graduates Association, UN, Durban, re Twenty-Fifth Anniversary Tragedy", South African Medical Journal, (13 March 1976).

Trouillot, M.R., Silencing the Past: Power and the Production of History (Beacon Press, Boston, 1995).

Vietzen, S., "Mabel Palmer and Black Higher Education in Natal, 1936-1942", Journal of Natal and Zulu History, 6, 1 (1983).

Watts, H.L., "Black Doctors: An Investigation into Aspects of the Training and Career of Students and Graduates from the Medical School of the University of Natal. Part I: "The Students" (Institute for Social Research, University of Natal, Durban, 1975).

White, H., Tropics of Discourse: Essays in Cultural Criticism (Johns Hopkins University Press, Baltimore, 1985). 